\title{
PERSEPSI SISWA TERHADAP KOMPETENSI GURU YANG SUDAH DAN BELUM DISERTIFIKASI ${ }^{1}$
}

\section{STUDENTS' PERCEPTION OF THE COMPETENCE OF CERTIFIED AND UNCERTIFIED TEACHERS}

\author{
Simon Sili Sabon \\ Pusat Penelitian Kebijakan, Balitbang Kemendikbud \\ JI. Jenderal Sudirman, Senayan Jakarta Pusat \\ e-mail: simonsilisabon@yahoo.com
}

Naskah diterima tanggal: 13-12-2016, disetujui tanggal: 28-06-2017

\begin{abstract}
This study is to get policy recommendation to improve the professionalism of teachers. The objective of this study will compare the students' perception about their teacher's competences of the certified and the uncertified ones, at: 1) public primary school 2) private primary school, 3) public junior high schools and 4) private junior high school. The used data are the primary data of students' perception about teacher's competence. The collected data were analyzed using descriptive statistics quantitative by comparing the proportion of each group of students in assessing the competences of their teacher. The results of the study: 1) the competence of the certified teachers at public primary school is better than the uncertified teachers, 2) the competence of the certified teachers at private primary school is better than the uncertified teachers, 3) the competence of the uncertified teachers at public junior secondary school is better than the certified teachers, and 4) the competence of the uncertified teachers at private junior secondary school is better than the certified teachers. To conclude the students' perception of the competence of teachers as follows: 1) at public and private primary school, the competence of the certified teachers is better than the uncertified teachers, 2) at public and private junior secondary school, the competence of uncertified teachers is better than the certified teachers.
\end{abstract}

Keywords: teachers' competence, teachers' certification, students' perception

\begin{abstract}
Abstrak: Penelitian ini untuk mendapatkan rekomendasi kebijakan untuk meningkatkan profesionalisme guru. Secara khusus tujuan penelitian ini adalah melakukan analisis perbandingan persepsi siswa tentang kompetensi guru antara: 1) guru SD negeri yang sudah dan belum disertifikasi, 2) guru SD swasta yang sudah dan belum disertifikasi, 3) guru SMP negeri yang sudah dan belum disertifikasi dan 4) guru SMP swasta yang sudah dan belum disertifikasi. Data yang digunakan dalam pengkajian ini adalah data primer persepsi siswa tentang kompetensi guru. Data yang terkumpul dianalisis menggunakan statistik deskriptif kuantitatif dengan membandingkan proporsi setiap kelompok siswa dalam memberikan penilaian terhadap kompetensi gurunya. Hasil kajian: 1) kompetensi guru SD negeri yang sudah disertifikasi lebih baik daripada yang belum disertifikasi, 2) kompetensi guru SD swasta yang sudah disertifikasi lebih baik daripada yang belum disertifikasi, 3) kompetensi guru SMP negeri yang belum disertifikasi lebih baik daripada yang sudah disertifikasi, dan 4) kompetensi guru SMP swasta yang belum disertifikasi lebih baik daripada yang sudah disertifikasi. Kajian ini menyimpulkan persepsi siswa terhadap kompetensi gurunya sebagai berikut: 1) di SD (negeri dan swasta), kompetensi guru yang sudah
\end{abstract}

\footnotetext{
1 Kajian ini merupakan bagian dari hasil survei "Perbandingan Kinerja Guru Bersertifikat Pendidik dan Yang Belum Bersertifikat Pendidik" pada tahun 2010 di Puslitjak Balitbang Kemendikbud, yang disponsori oleh Bank Dunia. Penulis sebagai salah satu anggota tim dalam survei tersebut.
} 
disertifikasi lebih baik daripada guru yang belum disertifikasi bersertifikat, dan 2) di SMP (negeri dan swasta) kompetensi guru yang belum disertifikasi lebih baik daripada yang sudah disertifikasi.

Kata kunci: Kompetensi guru, sertifikasi guru, persepsi siswa

\section{PENDAHULUAN}

Pemerintah telah melakukan berbagai upaya agar guru menjadi pendidik profesional. Setiap guru diharapkan mampu menjalankan tugas dan fungsinya untuk mendidik, mengajar, membimbing, mengarahkan, melatih, menilai, dan mengevaluasi peserta didik, dalam rangka mewujudkan pendidikan yang bermutu. Guru sebagai agen pembelajaran dituntut mampu bekerja secara profesional. Profesionalisme guru dalam mendidik, mengajar, membimbing, mengarahkan, melatih, menilai, dan mengevaluasi peserta didik telah ditegaskan dalam peraturan perundang-undangan seperti Undang-Undang Nomor 14 Tahun 2005 tentang Guru dan Dosen (Republik Indonesia, 2005). Berdasarkan peraturan tersebut, guru dituntut memiliki sertifikat pendidik, sebagai cerminan kompetensi guru pada aspek pedagogik, kepribadian, sosial, dan profesional yang diperoleh melalui pendidikan profesi.

Kendati pemerintah telah berupaya untuk terus meningkatkan profesionalisme guru, namun belum menghasilkan kompetensi seperti yang diharapkan. Sejak lama guru ditengarai tidak layak mengajar sebagaimana disampaikan oleh Jailani (2014). Disebutkan bahwa kualitas guru dan pendidikan di Indonesia berada pada kondisi yang memprihatinkan. Jailani mengungkapkan ini berdasarkan pada data tahun 2002-2003 dimana sebanyak 78,93 guru SD negeri, 71,06\% guru SD swasta, $45,88 \%$ guru SMP negeri, $31,01 \%$ guru SMP swasta, 34,71\% guru SMA negeri, 35,27\% guru SMA swasta, 44,51\% guru SMK negeri dan $41,74 \%$ guru SMK swasta tidak layak mengajar. Rendahnya kemampuan mengajar guru ini sudah sejak lama terjadi seperti disampaikan pada tahun 2007 oleh Fasli Djalal yang saat itu menjabat sebagai Direktur Jenderal Direktorat Jenderal Peningkatan Mutu
Pendidik dan Tenaga Kependidikan (Dirjen Ditjen PMPTK). Disebutkan bahwa hampir separoh dari sekitar 2,6 juta guru di Indonesia tidak layak mengajar di sekolah (Sari, 2014). Natsir (2007) mengungkapkan pula bahwa kompetensi guru untuk mengajar pada berbagai satuan pendidikan masih rendah, sehingga banyak guru tidak layak mengajar. Persentase guru menurut kelayakan mengajar dalam tahun 2002-2003 di berbagai satuan pendidikan adalah sebagai berikut: untuk SD yang layak mengajar hanya $21,07 \%$ (negeri) dan 28,94\% (swasta), untuk SMP 54,12\% (negeri) dan 60,99\% (swasta), untuk SMA 65,29\% (negeri) dan 64,73\% (swasta), serta untuk SMK yang layak mengajar $55,49 \%$ (negeri) dan 58,26\% (swasta).

Dari data dan informasi yang disampaikan di atas dapat disimpulkan bahwa sebagian guru pada berbagai jenjang dan satuan pendidikan tidak layak mengajar, karena mereka tidak memiliki kompetensi yang memadai untuk menjadi seorang guru yang profesional. Untuk itu Pemerintah terus berupaya melaksanakan berbagai langkah pembinaan agar guru menjadi layak mengajar. Salah satu cara yang telah ditempuh Pemerintah adalah dengan melakukan program sertifikasi guru. Dengan cara ini guru diharapkan dapat menjadi guru yang profesional khususnya dalam arti menjadi layak mengajar. Namun dengan banyaknya jumlah guru maka program sertifikasi tidak dapat dilaksanakan sekaligus, tetapi dilaksanakan secara bertahap.

Tabel 1 menggambarkan perkembangan data guru yang sudah dan belum disertifikasi sejak tahun 2009 hingga 2015. Data ini bersumber dari survei 'sertifikasi guru' program Better Education through Reformed Management and Universal Teacher Upgrading (BERMUTU) yang dilakukan Pusat Penelitian Kebijakan (Puslitjak) bekerja sama dengan Pusat 
Penilaian Pendidikan (Puspendik) dan Bank Dunia serta data tahun 2015 dari Direktorat Jenderal Guru dan Tenaga Kependidikan Kementerian Pendidikan dan Kebudayaan (Kementerian Pendidikan dan Kebudayaan, 2015a).

Dari Tabel 1 terlihat bahwa jumlah guru yang disertifikasi meningkat dari tahun ke tahun. Untuk mendapat gambaran tentang rendahnya kompetensi guru, khususnya untuk kompetensi profesional dan pedagogik disajikan hasil Uji Kompetensi Guru (UKG) 2015 yang diolah dari data UKG 2015 (lihat Tabel 2).

Tabel 2 menunjukkan bahwa rerata nilai UKG guru SD tidak banyak berbeda antara guru yang sudah dan belum disertifikasi. Yang menarik adalah bahwa kompetensi guru SD yang belum disertifikasi justru sedikit lebih tinggi daripada guru yang sudah disertifikasi. Jika dibandingkan dengan hasil UKG guru SMP maka nilai UKG guru SMP yang sudah disertifikasi sedikit lebih tinggi daripada guru yang belum disertifikasi. Ketika dibandingkan dengan Standar Kelulusan Minimal (SKM) yang ditetapkan untuk UKG 2015 yaitu sebesar 55,0, maka nilai UKG sebagian besar guru SD tidak mencapai SKM. Untuk guru-guru SMP rerata nilai UKG-nya memang lebih tinggi dari SKM namun tingginya standar deviasi menunjukkan bahwa banyak guru SMP nilai UKGnya pun tidak mencapai SKM.

Azizi (2010) juga mengungkapkan rendahnya kompetensi guru. Menurutnya salah satu penyebab rendahnya kompetensi guru adalah masih banyaknya guru yang mengajar tidak sesuai dengan bidangnya. Contoh kasus di MTs Sudirman Tempuran Kabupaten Magelang Jawa Tengah. Di MTs ini tercatat 75 persen guru yang mengajar tidak sesuai dengan latar belakang pendidikan atau bidangnya. Hal ini tentunya sangat memprihatinkan untuk dunia pendidikan. Rendahnya kompetensi guru ini tentunya akan berpengaruh pada kinerja guru, khususnya kinerja pembelajaran guru di dalam kelas. Salah satu indikator kinerja guru adalah hasil belajar siswa yang direfleksikan melalui rerata nilai UN. Karena di tingkat SD tidak ada Ujian Nasional (UN), rerata nilai UN SMP dalam dua tahun ajaran terakhir untuk memberikan gambaran tentang kinerja guru SMP. Tabel 3 menyajikan rerata nilai UN SMP dalam dua tahun terakhir mengalami penurunan. Rerata UN SMP pada tahun 2015 sedikit lebih tinggi dari 60, namun rerata nilai UN pada tahun 2016 justru di bawah 60. Angka ini tentunya menunjukkan kinerja guru masih belum memuaskan. Seharusnya semakin

Tabel 1 Jumlah Guru Berdasarkan Status Sertifikasi

\begin{tabular}{lrrrr}
\hline Status & \multicolumn{4}{c}{ Jumlah guru (\%) } \\
\cline { 2 - 5 } Sertifikasi & $2009 *)$ & $\left.2011^{*}\right)$ & $\left.2012^{*}\right)$ & $\left.2015^{*}\right)$ \\
\hline belum & 81,8 & 54,1 & 44,9 & 25,0 \\
sudah & 18,2 & 45,9 & 55,1 & 75,0 \\
\hline
\end{tabular}

Sumber: *) Kementerian Pendidikan dan Kebudayaan (2012).

**) Kementerian Pendidikan dan Kebudayaan (2015a)

Tabel 2 Nilai Ujian Kompetensi Guru Tahun 2015

\begin{tabular}{lcccc}
\hline \multicolumn{1}{c}{ Status } & \multicolumn{2}{c}{ SD } & \multicolumn{2}{c}{ SMP } \\
\cline { 2 - 5 } Sertifikasi & Rerata & Standar deviasi & Rerata & Standar deviasi \\
\hline Belum & 54,3 & 13,2 & 56,9 & 14,4 \\
Sudah & 54,2 & 12,6 & 60,4 & 14,1 \\
\hline
\end{tabular}

Sumber: Kementerian Pendidikan dan Kebudayaan (2015a). 
Tabel 3 Nilai UN yang Mengindikasikan Rendahnya Kinerja GuruTahun 2015 dan 2016

\begin{tabular}{lccc}
\hline Satuan Pendidikan & UN 2015 & UN 2016 & Selisih UN 2016 dan UN 2015 \\
\hline SMP & 62,18 & 58,57 & 3,61 \\
\hline
\end{tabular}

Sumber: Medistiara (2016)

profesional seorang guru yang ditandai dengan kepemilikan sertifikat pendidik, semakin baik kinerjanya. Didasarkan kenyataan tersebut perlu diadakan pengkajian terkait kompetensi guru guna mencari solusi dalam meningkatkan kompetensi guru. Adanya kebijakan sertifikasi berimplikasi kepada Pemerintah yang harus menyediakan dana untuk membayar Tunjangan Profesi Guru (TPG). Pemerintah tentunya ingin mendapat manfaat dari TPG yang dibayarkannya tersebut, yaitu kompetensi guru yang semakin membaik di dalam kelas bermuara pada semakin meningkatnya nilai UN siswa dari tahun ke tahun.

Syarat utama untuk dapat menjadi pendidik yang profesional, guru harus memiliki latar belakang pendidikan yang sesuai dengan mata pelajaran yang diampu, sedangkan untuk memenuhi persyaratan kompetensi, guru harus dapat membuktikan kepemilikan kompetensi tersebut dengan sertifikat pendidik yang diperoleh melalui sertifikasi. Sertifikasi guru merupakan upaya peningkatan mutu guru yang dibarengi dengan peningkatan kesejahteraan guru, sehingga diharapkan dapat meningkatkan mutu pembelajaran dan mutu pendidikan di Indonesia secara berkelanjutan (Sunhaji, 2014).

Apabila guru mengajar di sekolah hanya sekedar untuk menjalankan tugasnya sebagai suatu kewajiban, maka kegiatan belajar mengajar akan dapat membosankan dan tidak mencapai hasil yang maksimal. Karena itu, guru diharapkan dapat melaksanakan tugasnya secara profesional. Namun fakta menunjukkan bahwa sebagian guru belum memenuhi tuntutan peraturan perundang-undangan yaitu bahwa seorang guru harus memiliki kualifikasi pendidikan S1 atau D-IV yang linear serta memiliki empat kompetensi yang memadai yaitu kepribadian, sosial, pedagogik dan profesional. Dalam Tabel 4 disajikan data guru yang belum memenuhi persyaratan kualifikasi pendidikan S1/D-IV.

Dari Tabel 4 terlihat bahwa masih terdapat sekitar 15, 5 persen guru yang belum memenuhi tuntutan undang-undang bahwa seorang guru harus memiliki kualifikasi pendidikan (ijasah) S1/ D-IV. Selanjutnya dalam Tabel 5 disajikan data hasil UKG yang menunjukkan bahwa kompetensi guru khususnya kompetensi profesional dan pedagogik masih belum memadai. Terlihat dari Tabel 5 bahwa nilai UKG dari tahun ke tahun terus meningkat namun hasilnya masih belum memuaskan.

Guru profesional yang memenuhi persyaratan yang ditetapkan, akan mendapat tunjangan profesi minimal sebesar satu kali gaji pokok. Diharapkan kompetensi guru yang sudah disertifikasi dan memperoleh tambahan kesejahteraan, akan lebih baik daripada guru belum

Tabel 4 Data Guru Berdasarkan Kualifikasi Pendidikan

\begin{tabular}{|c|c|c|c|}
\hline \multirow{2}{*}{$\begin{array}{l}\text { Satuan } \\
\text { pendidikan }\end{array}$} & \multirow{2}{*}{ Jumlah guru } & \multicolumn{2}{|c|}{ Kualifikasi pendidikan } \\
\hline & & $<\mathrm{S} 1$ & $\geq \mathrm{S} 1$ \\
\hline SD & 1.648 .077 & 19,7 & 80,3 \\
\hline SMP & 644.399 & 13,2 & 86,8 \\
\hline SMA & 283.223 & 3,9 & 96,1 \\
\hline SMK & 260.694 & 7,8 & 92,2 \\
\hline Total & 2.836 .393 & 15,5 & 84,5 \\
\hline
\end{tabular}

Sumber: Kementerian Pendidikan dan Kebudayaan (2015b). 
Tabel 5 Perkembangan nilai UKG 2012-2015

\begin{tabular}{ccccc}
\hline Uraian & \multicolumn{4}{c}{ Tahun pelaksanaan UKG } \\
\cline { 2 - 4 } Rerata nilai UKG guru & 2012 & 2013 & 2014 & 2015 \\
\hline
\end{tabular}

Sumber: Kementerian Pendidikan dan Kebudayaan. 2015a

disertifikasi. Berdasarkan uraian ini, maka permasalahan penelitian pengkajian ini secara khusus dirumuskan melalui empat pertanyaan pengkajian sebagai berikut: 1) bagaimana perbandingan kompetensi antara guru SD negeri yang sudah dan belum disertifikasi, 2) bagaimana perbandingan kompetensi antara guru SD swasta yang sudah dan belum disertifikasi, 3) bagaimana perbandingan kompetensi antara guru SMP negeri yang sudah dan belum disertifikasi; dan 4) bagaimana perbandingan kompetensi antara guru SMP swasta yang sudah dan belum disertifikasi.

Sesuai dengan rumusan permasalahan tersebut, penelitian ini bertujuan untuk menganalisis: 1) perbandingan kompetensi antara guru SD negeri yang sudah dan belum disertifikasi, 2) perbandingan kompetensi antara guru SD swasta yang sudah dan belum disertifikasi, 3) perbandingan kompetensi antara guru SMP negeri yang sudah dan belum disertifikasi, dan 4) perbandingan kompetensi antara guru SMP swasta yang sudah dan belum disertifikasi, dalam rangka memperoleh rekomendasi kebijakan guna meningkatkan profesionalisme guru.

Kajian ini bermanfaat bagi pemerintah, pemerintah daerah dan juga guru sebagai objek yang diteliti. Bagi pemerintah dalam hal ini Direktorat Jenderal Guru dan Tenaga Kependidikan (Ditjen GTK) Kemendikbud dan dinas pendidikan kabupaten/kota antara lain mendapat masukan tentang bagaimana kompetensi guru yang telah disertifikasi dibandingkan dengan yang belum disertifikasi, sehingga dapat menjadi dasar pengambilan kebijakan dalam mengadakan pelatihan yang lebih terfokus pada peningkatan kompetensi tertentu dalam rangka pembinaan profesionalisme guru yang berkelanjutan di masa yang akan datang. Bagi guru sebagai objek penelitian, kajian ini akan memberikan masukan bagi guru khususnya bagi yang sudah disertifikasi agar terus mengevaluasi diri dan terus meningkatkan kompetensi dan kinerjanya, jika temuan kajian menunjukkan bahwa kompetensi guru baik sudah maupun belum disertifikasi adalah sama atau kompetensi guru belum disertifikasi justru lebih baik daripada yang sudah disertifikasi.

Pada hakikatnya, guru merupakan profesi yang mulia. Mustofa (2007) mengungkapkan bahwa profesi guru merupakan profesi yang sangat penting dalam kehidupan suatu bangsa. Guru merupakan unsur dominan dalam suatu proses pendidikan, sehingga kualitas pendidikan banyak ditentukan oleh kualitas pendidik dalam menjalankan peran dan tugasnya di masyarakat. Upaya-upaya untuk terus mengembangkan profesi guru menjadi suatu syarat mutlak bagi kemajuan suatu bangsa. Meningkatnya kualitas pendidik akan mendorong peningkatan kualitas pendidikan baik proses maupun hasilnya. Rohman (2007) mendefinisikan guru adalah orang yang bertanggung jawab terhadap perkembangan seluruh potensi anak didik, baik potensi afektif, kognitif, maupun psikomotorik. Setyawan (2013) mengungkapkan bahwa guru sebagai pengajar anak, diibaratkan seperti ibu kedua yang mengajarkan berbagai macam hal baru dan sebagai fasilitator, agar anak dapat belajar dan mengembangkan potensi dasar dan kemampuannya secara optimal, hanya saja ruang lingkupnya guru berbeda, guru mendidik dan mengajar di sekolah. Setyawan Ialu mendefenisikan bahwa guru adalah pendidik, yaitu orang dewasa yang bertanggung jawab memberi bimbingan atau bantuan kepada anak didik dalam perkembangan jasmani dan rohaninya agar mencapai kedewasaannya, mampu berdiri sendiri dan dapat melaksanakan 
tugasnya. Sejalan dengan ini, Apriliani (2015) mengungkapkan bahwa guru merupakan salah satu profesi yang berkaitan dengan pelaksanaan aktivitas pada bidang pendidikan dan bahwa guru adalah pendidik yang berada di lingkungan sekolah.

Dari defenisi tersebut, dapat disimpulkan bahwa guru adalah seseorang yang memiliki kemampuan untuk merancang program pembelajaran serta mampu menata dan mengelola kelas agar siswa dapat belajar dan dapat mencapai tingkat kedewasaan, sehingga guru bertanggung jawab terhadap perkembangan seluruh potensi siswa, baik potensi afektif, kognitif, maupun psikomotorik. Untuk dapat melaksanakan tanggung jawab tersebut, guru harus menguasai keterampilan-keterampilan dasar dalam mengajar. Siswanto (2010) mengemukakan bahwa ada sepuluh keterampilan dasar mengajar yang perlu dikuasai oleh seorang guru, yakni: 1) keterampilan membuka dan menutup pelajaran: kegiatan membuka pelajaran adalah kegiatan yang dilakukan guru untuk menciptakan suasana pembelajaran yang memungkinkan siswa siap secara mental untuk mengikuti kegiatan pembelajaran. Kegiatan menutup pelajaran adalah kegiatan yang dilakukan guru untuk mengakhiri kegiatan inti pembelajaran; 2) keterampilan menjelaskan adalah memberikan informasi yang diorganisasi secara sistematis kepada siswa; 3) keterampilan memberi penguatan: penguatan adalah tanggapan guru terhadap perilaku siswa yang memungkinkan dapat membesarkan hati siswa agar lebih terpacu dalam interaksi belajarmengajar; 4) keterampilan menggunakan media dan alat pembelajaran: media dan alat pembelajaran yang dipergunakan dalam proses pembelajaran agar siswa memperoleh kemudahan dalam memahami materi pembelajaran; 5) keterampilan menyusun skenario/pembelajaran langkah-langkah kegiatan pembelajaran yang akan ditempuh oleh guru dan siswa dalam rangka membelajarkan siswa yang meliputi pengetahuan, keterampilan dan sikap; 6) keterampilan mengadakan variasi: variasi dalam kegiatan pembelajaran adalah perubahan yang dilakukan guru dalam kegiatan pembelajaran yang meliputi gaya belajar, penggunaan media pembelajaran, pola interaksi dan stimulasi; 7) keterampilan membimbing diskusi: diskusi adalah suatu proses interaksi verbal secara teratur yang melibatkan sekelompok orang dalam interaksi tatap muka yang informal dengan tujuan berbagi pengalaman atau informasi, mengkonstruk konsep, mengambil suatu keputusan atau memecahkan masalah; 8) keterampilan mengelola kelas: mengelola kelas adalah menciptakan dan memelihara kondisi belajar yang optimal bagi siswa dan mengembalikan ke kondisi belajar yang optimal apabila terdapat gangguan dalam proses pembelajaran; 9) keterampilan bertanya: adalah tentang bagaimana guru menyampaikan pertanyaan kepada siswa dalam proses pembelajaran, baik pertanyaan dasar maupun pertanyaan lanjut; dan 10) keterampilan mengevaluasi: evaluasi adalah proses sistematis untuk mengetahui efektivitas dan efisiensi suatu kegiatan pembelajaran. Jika guru memiliki sepuluh keterampilan tersebut niscaya guru akan menjadi lebih mudah dalam mentransfer ilmunya kepada peserta didik.

Guru dinilai bekerja profesional jika dapat menunjukkan kinerjanya. Suharso (2014) mengungkapkan seorang guru profesional apabila yang bersangkutan mampu mengerjakan tugasnya dengan selalu berpegang teguh pada etika kerja, independent (bebas dari tekanan pihak luar), produktif, efektif, efisien, dan inovatif serta didasarkan pada prinsip-prinsip pelayanan prima yang didasarkan pada unsurunsur ilmu atau teori yang sistematis, kewenangan profesional, pengakuan masyarakat dan kode etik yang regulatif. Profesionalisme guru diperlihatkan dari kinerja sebagai guru, sehingga perlu dipahami mengenai konsep kinerja dan kinerja guru. Alim (2013) mendefinisikan kinerja sebagai hasil kerja secara kualitas dan kuantitas yang dapat dicapai oleh seorang pegawai dalam melaksanakan tugas pokok dan fungsinya sesuai dengan tanggung jawab yang dibebankan atau 
diberikan kepadanya. Kinerja pada dasarnya dapat dilihat dari dua segi, yaitu kinerja pegawai (per individu) dan kinerja organisasi. Kinerja pegawai adalah hasil kerja perseorangan dalam suatu organisasi, sedangkan kinerja organisasi adalah totalitas hasil kerja yang dicapai suatu organisasi. Selanjutnya, Lestari (2010) mendefinisikan kinerja guru sebagai hasil kerja yang dicapai oleh guru dalam pencapaian tujuan pendidikan yang tidak hanya dalam bidang mengajar di dalam kelas, tetapi juga kinerja di luar kelas dalam arti di luar mengajar, misalnya dalam mengelola administrasi siswa. Dengan demikian, istilah kinerja mempunyai pengertian akan adanya suatu tindakan atau kegiatan yang ditampilkan oleh seseorang dalam melaksanakan aktivitas tertentu. Kinerja seseorang akan tampak pada situasi dan kondisi kerja seharihari.

Dari definisi kinerja dan kinerja guru dapat disimpulkan bahwa kinerja adalah hasil kerja secara kualitas dan kuantitas yang dapat dicapai oleh seorang pegawai/karyawan, sedangkan kinerja guru adalah hasil kerja yang dicapai oleh seorang guru dalam mencapai tujuan pendidikan. Guru dapat memberikan kinerja yang baik apabila dapat melaksanakan paling sedikit 10 peran, sebagaimana disampaikan oleh Mudri (2010). Pertama, guru sebagai pendidik: guru menjadi tokoh, panutan, dan identifikasi bagi para peserta didik, dan lingkungannya. Kedua, guru sebagai pengajar: sejak adanya kehidupan, sejak itu pula guru telah melaksanakan pembelajaran, dan hal tersebut merupakan tugas dan tanggung jawabnya yang pertama dan utama. Ketiga, guru sebagai pembimbing: guru dapat diibaratkan sebagai pembimbing perjalanan (guide), yang berdasarkan pengetahuan dan pengalamannya bertanggung jawab atas kelancaran perjalanan itu. Keempat, guru sebagai pelatih: proses pendidikan dan pembelajaran memerlukan latihan keterampilan, baik intelektual maupun motorik, sehingga menuntut guru untuk bertindak sebagai pelatih. Kelima, guru sebagai penasihat: guru adalah seorang penasihat bagi peserta didik, bahkan bagi orangtua, meskipun mereka tidak memiliki latihan khusus sebagai penasihat dan dalam beberapa hal tidak dapat berharap untuk menasihati orang. Keenam, guru sebagai model dan teladan: guru merupakan model atau teladan bagi para peserta didik dan semua orang yang menganggap dia sebagai guru. Ketujuh, guru sebagai pendorong kreativitas: kreativitas merupakan hal yang sangat penting dalam pembelajaran, dan guru dituntut untuk mendemonstrasikan dan menunjukkan proses kreativitas tersebut. Kedelapan, guru sebagai aktor: sebagai seorang aktor, guru harus melakukan apa yang ada dalam naskah yang telah disusun dengan mempertimbangkan pesan yang akan disampaikan kepada penonton. Kesembilan, guru sebagai emansipator: dengan kecerdikannya, guru mampu memahami potensi peserta didik, menghormati setiap insan. Kesepuluh, guru sebagai evaluator: evaluasi atau penilaian merupakan aspek pembelajaran yang paling kompleks, karena melibatkan banyak latar belakang dan hubungan, serta variabel lain yang mempunyai arti apabila berhubungan dengan konteks yang hampir tidak mungkin dapat dipisahkan dengan setiap segi penilaian.

Guru akan mampu melaksanakan kinerja secara profesional jika menguasai kompetensi sebagai guru. Apa itu kompetensi guru? Siswanto (2008) mendefinisikan bahwa kompetensi (competency) merupakan kebulatan penguasaan pengetahuan, keterampilan, dan sikap melalui unjuk kerja dan diharapkan bisa dicapai seseorang setelah menyelesaikan suatu program pendidikan. Menurut Setyaningsih (2015) kompetensi guru adalah pengetahuan, keterampilan dan kemampuan yang dikuasai oleh seorang guru meliputi kompetensi pedagogik, kepribadian, sosial, dan profesional yang telah menjadi bagian dari dalam diri guru, sehingga ia dapat melakukan perilaku kognitif, afektif dan psikomotorik dengan sebaik-baiknya. Menurut Novauli (2015) kompetensi guru diartikan sebagai penguasaan terhadap suatu tugas (mengajar dan mendidik), keterampilan, sikap dan apresiasi yang diperlukan untuk menunjang keberhasilan 
proses pendidikan yang dilakukannya. Dari defenisi-defenisi tersebut dapat disimpulkan bahwa kompetensi guru adalah pengetahuan, keterampilan, dan kemampuan yang harus dikuasai dan dimiliki oleh seorang guru agar mampu melaksanakan kegiatan belajar mengajar dengan baik dan profesional. Kompetensi tidak hanya berkenaan dengan kemampuan guru dalam menyajikan pelajaran di depan kelas, melainkan termasuk keterampilan guru dalam mendidik dan menanamkan sikap yang baik kepada anak didik. Disebutkan Novauli (2015) bahwa seorang guru profesional bukanlah hanya untuk satu kompetensi saja yaitu kompetensi profesional, tetapi guru profesional harus mampu memiliki empat kompetensi sebagaimana yang diamanatkan Undang-Undang Nomor 14 Tahun 2005 tentang Guru dan Dosen, agar guru memahami, menguasai, dan terampil menggunakan sumber-sumber belajar baru dan menguasai kompetensi pedagogik, kepribadian, profesional, dan sosial sebagai bagian dari kemampuan guru. Kompetensi yang dimiliki oleh setiap guru akan menunjukkan kualitas guru yang sebenarnya, kompetensi tersebut akan terwujud dalam bentuk penguasaan pengetahuan, keterampilan maupun sikap profesional dalam menjalankan fungsi sebagai guru.

Kinerja dan kompetensi guru perlu dievaluasi dan dinilai secara periodik untuk mengetahui kondisi kinerja atau kompetensi guru guna diadakan upaya-upaya perbaikan jika ada kinerja atau kompetensi guru yang kurang memuaskan. Jadi, penilaian terhadap kompetensi dan kinerja guru sangat bermanfaat untuk tetap mempertahankan atau meningkatkan kompetensi dan kinerja guru. Hal tersebut secara rinci dijelaskan oleh Qurrotu (2011) dalam sembilan penilaian. Pertama, performance improvement: performance improvement berbicara mengenai umpan balik atas kinerja yang bermanfaat bagi karyawan, manajer, supervisor, dan spesialis sumber daya manusia (SDM) dalam bentuk kegiatan yang tepat untuk memperbaiki kinerja di masa yang akan datang. Kedua, compensation adjustment: penilaian kinerja membantu dalam pengambilan keputusan siapa yang seharusnya menerima kenaikan pembayaran dalam bentuk upah, bonus ataupun bentuk lainnya yang didasarkan pada suatu sistem tertentu. Ketiga, placement decision: kegiatan promosi, atau demosi jabatan dapat didasarkan pada kinerja masa lalu dan bersifat antisipatif, seperti dalam bentuk penghargaan terhadap karyawan yang memiliki hasil kinerja baik pada tugas-tugas sebelumnya. Keempat, training and development needs: kinerja yang buruk mengindikasikan sebuah kebutuhan untuk melakukan pelatihan kembali sehingga setiap karyawan hendaknya selalu memiliki kemampuan untuk mengembangkan diri agar sesuai dengan tuntutan jabatan saat ini. Kelima, career planing and development: umpan balik kinerja sangat membantu dalam proses pengambilan keputusan utamanya tentang karir spesifik dari karyawan, sebagai tahapan untuk pengembangan diri karyawan tersebut. Keenam, staffing process deficiencies: baik buruknya kinerja berimplikasi dalam hal kekuatan dan kelemahan dalam prosedur penempatan di departemen SDM. Ketujuh, informational inaccuracies: kinerja yang buruk dapat mengindikasikan adanya kesalahan dalam informasi analisis pekerjaan, perencanaan SDM, atau hal lain dari sistem manajemen SDM. Hal demikian akan mengarah pada ketidaktepatan dalam keputusan mempekerjakan karyawan, pelatihan dan keputusan konseling. Kedelapan, job design error: kinerja yang buruk mungkin sebagai suatu gejala dari rancangan pekerjaan yang salah atau kurang tepat. Melalui penilaian kinerja dapat didiagnosis kesalahan-kesalahan tersebut. Kesembilan, feedback to human resourches: kinerja yang baik dan buruk di seluruh perusahaan mengindikasikan bagaimana baiknya fungsi departemen SDM yang diterapkan.

Sebagai guru profesional, setiap guru diwajibkan untuk memperoleh sertifikat pendidik. Wuryanti dkk. (2014) mengungkapkan bahwa sertifikasi guru adalah proses pemberian sertifikat pendidik kepada guru yang telah memenuhi standar profesional guru dan 
menurutnya guru profesional merupakan syarat mutlak untuk menciptakan sistem dan praktik pendidikan yang berkualitas. Lebih lanjut Siswanto (2008) menyampaikan bahwa sertifikat pendidik adalah bentuk penghargaan yang diberikan kepada guru yang lulus sertifikasi, karena memenuhi persyaratan yaitu menguasai empat kompetensi sebagai agen pembelajaran meliputi kompetensi kepribadian, pedagogik, profesional dan sosial. Jadi, sertifikasi guru merupakan proses uji kompetensi bagi calon guru atau guru yang ingin memperoleh pengakuan dan atau meningkatkan kompetensi sesuai profesi yang dipilinnya. Representasi pemenuhan standar kompetensi yang telah ditetapkan dalam sertifikasi guru adalah sertifikat pendidik. Sertifikat ini sebagai bukti pengakuan atas kompetensi guru atau calon guru yang memenuhi standar untuk melakukan pekerjaan profesi guru pada jenis dan jenjang pendidikan tertentu. Dengan kata lain sertifikasi guru merupakan pemenuhan kebutuhan untuk meningkatkan kompetensi profesional. Oleh karena itu, proses sertifikasi dipandang sebagai bagian esensial dalam upaya memperoleh sertifikat pendidik sesuai dengan standar yang telah ditetapkan. Dari defenisi yang ada dapat disimpulkan bahwa sertifikasi guru adalah proses pemberian sertifikat pendidik kepada guru sebagai bukti pengakuan atas kompetensi guru yang memenuhi standar untuk melakukan pekerjaan profesi guru pada jenis dan jenjang pendidikan tertentu.

Hasbullah (2010) mengungkapkan bahwa guru yang telah memiliki sertifikat pendidik berhak atas Tunjangan Profesi Guru (TPG) sebesar satu kali gaji pokoknya. Persyaratan untuk mendapatkan TPG yaitu, memenuhi persyaratan akademik sebagai guru, memiliki sertifikat pendidik yang telah diberi satu nomor registrasi guru oleh Kementerian Pendidikan dan Kebudayaan (Kemendikbud), memenuhi beban kerja minimal sebagai guru, mengajar sebagai guru sesuai dengan peruntukan sertifikat pendidik yang dimilikinya, terdaftar pada Kemendikbud sebagai guru, melaksanakan kewajiban sebagai guru, tidak terikat sebagai tenaga tetap pada instansi sebagai guru. Lebih lanjut Baeti (2015) mengungkapkan bahwa program sertifikasi merupakan upaya untuk meningkatkan kualitas guru diikuti dengan pemberian TPG sebagai kompensasi atau "imbalan" bagi peningkatan kesejahteraan. TPG adalah tunjangan yang diberikan kepada guru yang telah memiliki sertifikat pendidik dan memenuhi persyaratan lainnya. Salah satu persyaratan utama guru menerima TPG adalah selain memiliki sertifikat pendidik, guru tersebut baik yang mengajar sebagai guru kelas maupun sebagai guru mata pelajaran, harus mengajar sekurang-kurangnya 24 Jam Tatap Muka (JTM) per minggu atau memiliki beban kerja yang diakui setara 24 JTM per minggu. Dari uraian ini dapat disimpulkan bahwa TPG merupakan bagian dari upaya pemerintah untuk meningkatkan profesionalisme guru, artinya bukan hanya kompetensi guru ditingkatkan tetapi juga kesejahteraan guru, sehingga harkat dan martabat guru dapat ditingkatkan.

Kajian terdahulu tentang perbandingan kompetensi guru yang sudah dan belum disertifikasi menunjukkan adanya kecenderungan bahwa guru yang telah disertifikasi dengan yang belum disertifikasi kompetensinya tidak jauh berbeda. Penelitian tentang "Dampak Kebijakan Sertifikasi Terhadap Kinerja Guru Di Daerah Riau" yang dilakukan Suarman \& Syahza (2014) di tiga kabupaten yakni Pelalawan, Kampar dan Rokan Hulu di Provinsi Riau ditemukan bahwa dari segi kemampuan pedagogik, guru yang sudah disertifikasi, kemampuan pedagogiknya sebagai guru tidak berbeda secara statistik dengan guru yang belum disertifikasi. Artinya cara guru mengajar maupun persiapan dalam pelaksanaan proses belajar mengajar (PBM) belum berbeda secara nyata. Dari sisi kemampuan profesional temuannya juga sama. Kinerja guru yang sudah disertifikasi dan yang belum disertifikasi menunjukkan tidak ada perbedaan. Indikator kemampuan profesional yang dinilai adalah penguasaan materi, struktur, konsep dan pola pikir keilmuan yang mendukung mata pelajaran yang diampu. 
Brotosedjati (2012) juga melakukan penelitian serupa yang dilakukan di 35 kabupaten/ kota di Jawa Tengah dengan jumlah responden sebanyak 1.540 orang yang berasal dari 20 jenis sekolah mulai dari TK/RA sampai SMA/SMK negeri maupun swasta. Hasil kajiannya menunjukkan sertifikasi telah dapat meningkatkan kesejahteraan, martabat guru, kedisiplinan dan kompetensi pedagogis guru, namun sertifikasi tidak banyak mengubah kinerja seorang guru karena baik guru yang telah disertifikasi maupun yang belum disertifikasi sama-sama konsisten melakukan perubahan ke arah yang lebih baik dengan atau tanpa adanya sertifikasi.

Hasil temuan kajian Nasir, dkk. (2013) mengungkapkan bahwa dari segi kemampuan pedagogik, kinerja guru Biologi yang sudah disertifikasi lebih baik daripada yang belum disertifikasi. Perbedaan ini secara statistik signifikan. Namun demikian dari segi kemampuan profesional kinerja guru Biologi yang sudah disertifikasi tidak berbeda dari yang belum disertifikasi.

Hasil kajian terdahulu dengan topik-topik yang serupa ini yaitu membandingkan kinerja atau kompetensi pedagogik dan profesional antara guru yang sudah dan belum disertifikasi menunjukkan temuan yang kurang lebih sama yaitu bahwa tidak terdapat perbedaan kinerja yang berarti antara guru yang sudah dan belum disertifikasi. Kajian Suarman \& Syahza (2014) menyimpulkan secara khusus bahwa kompetensi pedagogik dan profesional guru tidak berbeda antara guru yang sudah dan belum disertifikasi. Hasil kajian Nasir dkk. (2013) dan Brotosedjati (2012) memang memberikan hasil yang sedikit berbeda khususnya terkait kompetensi pedagogik yaitu bahwa kompetensi pedagogik guru yang sudah disertifikasi lebih baik daripada yang belum disertifikasi, namun itu semua dapat dipahami karena guru yang sudah mengikuti pelatihan untuk mendapat sertifikat pendidik tentunya mendapat pengetahuan baru tentang metode pembelajaran yang baru yang dapat diterapkannya di dalam kelas sehingga membuatnya berbeda dari guru yang belum disertifikasi. Lebih lanjut, kajian khusus oleh Nasir dkk. (2013) sangatlah kasuistis yaitu dilakukan hanya untuk guru Biologi saja kemudian lingkupnya pun sangat mikro yaitu di tingkat gugus atau rayon saja, sehingga hasilnya dapat berbeda dengan kajian lainnya yang lingkupnya lebih makro. Beberapa Hasil kajian tersebut jika dikaitkan dengan nilai UKG 2015 yang diutarakan sebelumnya, memperlihatkan bahwa hasilnya kurang lebih sama yaitu bahwa nilai kompetensi pedagogik dan profesional guru yang sudah dan belum disertifikasi kurang lebih sama. Bahkan hasil UKG 2015 menunjukkan bahwa rerata nilai UKG guru SD yang belum disertifikasi lebih baik daripada yang sudah disertifikasi (lihat Tabel 2).

Hipotesis awal dari kajian ini adalah bahwa kompetensi (profesional, pedagogik, kepribadian dan sosial) guru yang sudah disertifikasi lebih baik daripada guru yang belum disertifikasi. Selanjutnya disajikan kerangka berpikir dari pengkajian ini. Guru SD dan SMP baik negeri maupun swasta yang memenuhi persyaratan ditetapkan mengikuti program sertifikasi. Guru yang lulus sertifikasi dan memenuhi persyaratan mengajar mata pelajaran sesuai sertifikat pendidiknya sebanyak 24 Jam Tatap Muka (JTM) per minggu berhak mendapat TPG sebesar satu kali gaji pokok. Melalui program ini diharapkan agar kompetensi guru meningkat atau harus lebih baik dibanding guru yang belum disertifikasi. Dari perspektif siswa, apakah kompetensi guru

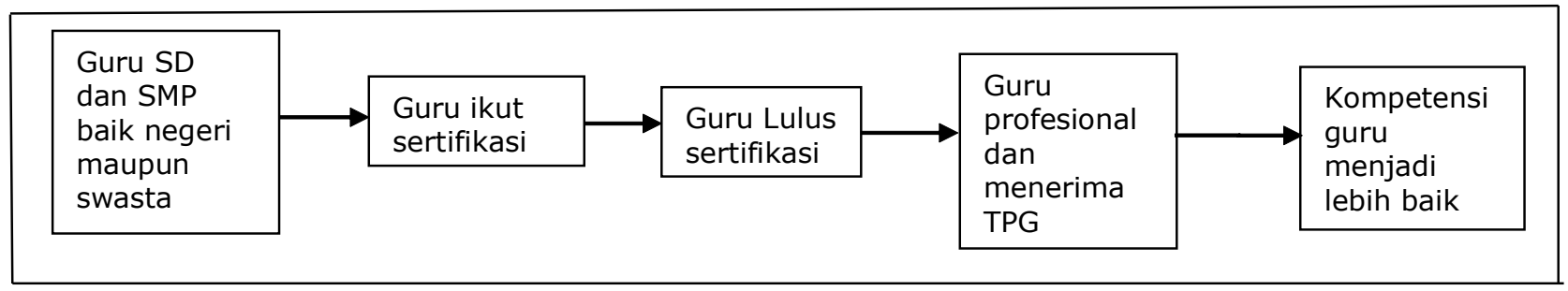

Gambar 1 Kerangka Berpikir Kajian 
yang sudah disertifikasi lebih baik daripada guru yang belum disertifikasi?

\section{METODE}

Pendekatan yang digunakan dalam kajian ini adalah kuantitatif. Populasi kajian ini guru SD dan SMP. Kajian ini memanfaatkan sebagian kecil data yang dikumpulkan dalam rangka survei "Perbandingan Kinerja Guru Yang Sudah Bersertifikat dan Belum Bersertifikat pendidik" yang dilaksanakan pada tahun 2010 pada proyek Better Education through Reformed Management and Universal Teacher Upgrading (BERMUTU) yang disponsori oleh Bank Dunia (Fajarini, dkk, 2010). Dengan demikian pengambilan sampel studi ini mengikuti survei tersebut. Pada tahap pertama ditetapkan sampel kabupaten/kota. Jumlah lokasi yang menjadi sampel ditetapkan sebanyak 20 kabupaten/kota. Proyek BERMUTU sendiri telah membagi wilayah Indonesia menjadi 10 wilayah berdasarkan letak geografi (lihat Tabel 6). Untuk itu sampel kabupaten/kota dipilih mewakili ke10 wilayah ini. Karena ditetapkan sampel sebanyak 20 kabupaten/kota, maka dari masing-masing wilayah dipilih dua kabupaten/ kota. Kedua kabupaten/kota tersebut salah satunya merupakan kabupaten yang ditetapkan menjadi sampel survei utama dari proyek BERMUTU yaitu 'Sertifikasi Guru' yang merupakan suatu survei longitudinal dari tahun 20092012. Kabupaten/kota sampel lainnya adalah salah satu kabupaten/kota yang memiliki kesamaan kondisi dengan kabupaten/kota sampel proyek BERMUTU. Khusus wilayah Indonesia Timur 1 dengan Kabupaten Maluku Tenggara Barat sebagai satu-satunya sampel survei 'Sertifikasi Guru' proyek BERMUTU, tidak dipilih sebagai sampel karena kabupaten ini telah mekar menjadi 2 kabupaten dan lokasinya terlalu terpencil sehingga sulit untuk mencapainya. Sebagai gantinya, di wilayah Sulawesi yang relatif mewakili Indonesia Timur diambil empat kabupaten sampel, yaitu Gowa dan ToliToli sebagai kabupaten/kota sampel survei 'Sertifikasi Guru' proyek BERMUTU, kemudian Donggala dan Pangkep sebagai kabupaten bukan sampel survei 'Sertifikasi Guru' proyek BERMUTU). Kesepuluh pembagian wilayah Indonesia berikut sampel kabupaten/kota yang terpilih disajikan dalam Tabel 6.

Tahap selanjutnya adalah pemilihan sekolah sampel. Sekolah yang dijadikan sampel adalah sekolah-sekolah dengan kriteria telah memiliki minimal dua guru yang sudah disertifikasi. Informasi tentang sekolah yang memenuhi

Tabel 6 Kabupaten/Kota Sampel

\begin{tabular}{|c|c|c|c|}
\hline No & Pembagian Wilayah & $\begin{array}{c}\text { Kabupaten/Kota } \\
\text { BERMUTU }\end{array}$ & $\begin{array}{c}\text { Kabupaten/Kota bukan } \\
\text { BERMUTU }\end{array}$ \\
\hline 1. & Indonesia Timur-1 (Papua/Maluku)*) & -- & -- \\
\hline 2. & Indonesia Timur-2 (Nusa Tenggara) & Lombok Timur & Flores Timur \\
\hline 3. & Jawa bagian Barat & Purwakarta & Sumedang \\
\hline 4. & Jawa bagian Tengah & Bantul & Kota Semarang \\
\hline 5. & Jawa bagian Timur (termasuk Bali) & Tuban & 4. Jember \\
\hline 6. & Kalimantan & 5. Hulu Sungai Selatan & 5. Kota Banjar Baru \\
\hline 7. & Sulawesi & $\begin{array}{l}\text { 6. Toli Toli } \\
\text { 7. Gowa }\end{array}$ & $\begin{array}{l}\text { 6. Donggala } \\
\text { 7. Pangkep }\end{array}$ \\
\hline 8. & Sumatera Bagian Utara & 8. Deli Serdang & 8. Asahan \\
\hline 9. & Sumatera Bagian Tengah & 9. Tebo & 9. Sijunjung \\
\hline 10. & Sumatra Bagian Selatan & 10. Ogan Ilir & 10. Lampung Selatan \\
\hline
\end{tabular}

Sumber: Fajarini dkk. (2010)

Keterangan*)Tidak dijadikan wilayah sampel karena satu-satunya kabupaten yang menjadi sampel studi Proyek BERMUTU di wilayah ini telah mekar menjadi dua kabupaten dan lokasinya sangat terpencil sehingga sulit dijangkau. 
persyaratan tersebut diperoleh dari dinas kabupaten/kota. Khusus untuk SD ada ekstra persyaratan yaitu memiliki minimal dua guru kelas $\checkmark$ atau VI yang sudah disertifikasi karena pertimbangan siswa di kelas ini dianggap sudah mampu dalam melakukan penilaian terhadap kinerja gurunya. Berdasarkan kriteria ini maka ditetapkan jumlah sekolah sampel pada setiap kabupaten/kota sebanyak delapan sekolah yaitu dua SD negeri, dua SD swasta, dua SMP negeri dan dua SMP swasta. Pada masing-masing sekolah dipilih empat orang guru untuk dinilai kinerjanya oleh siswa. Guru yang jadi sampel adalah dua orang guru yang sudah disertifikasi dan dua orang yang belum disertifikasi. Masingmasing guru dinilai oleh lima orang siswanya. Jadi pada setiap sekolah sampel terdapat empat orang guru yang dijadikan sampel dan masingmasing guru dinilai oleh lima orang siswa yang berbeda sehingga total responden siswa per sekolah adalah 20 siswa. Guna mendapat gambaran yang lebih jelas tentang jumlah sekolah sampel, jumlah guru sampel dan jumlah siswa yang menjadi responden untuk menilai gurunya di setiap kabupaten/kota disajikan dalam Tabel 7. Dari Tabel tersebut dapat dihitung jumlah sekolah sampel, jumlah guru sampel. Jumlah responden keseluruhan untuk kajian ini seperti disajikan dalam Tabel 8.

Data yang digunakan dalam kajian ini adalah data khusus tentang persepsi siswa terhadap kompetensi gurunya. Instrumen yang digunakan untuk mengumpulkan data ini adalah kuesioner yang berisi pertanyaan dengan jawaban 'Ya' atau 'Tidak'. Siswa diminta menilai gurunya apakah gurunya melakukan kegiatan tersebut dalam pembelajaran di kelas, atau guru bersikap/ berperilaku demikian sebagaimana yang diutarakan dalam pertanyaan. Pertanyaan yang diajukan kepada siswa dikelompokkan dalam dua kategori yaitu: terkait kegiatan pembelajaran yang dilakukan oleh guru di dalam kelas (meliputi kompetensi pedagogik dan profesional) dan terkait keseharian guru meliputi kompetensi kepribadian dan sosial. Total pertanyaan yang diajukan sebanyak 23 pertanyaan. Pertanyaan terkait pembelajaran oleh guru di kelas (mengukur kompetensi pedagogik dan profesional) terdiri atas 15 butir sedangkan pertanyaan terkait keseharian guru (mengukur

Tabel 7 Jumlah Sampel Sekolah dan Guru serta Responden Siswa per Kabupaten/Kota

\begin{tabular}{|c|c|c|c|c|c|}
\hline \multirow{2}{*}{ Uraian } & \multicolumn{2}{|c|}{ SD } & \multicolumn{2}{|c|}{ SMP } & \multirow{2}{*}{ Total } \\
\hline & negeri & swasta & negeri & swasta & \\
\hline Jumlah sekolah sampel & 2 & 2 & 2 & 2 & 8 \\
\hline Jumlah guru yang sudah disertifikasi & 4 & 4 & 4 & 4 & 16 \\
\hline Jumlah guru yang belum disertifikasi & 4 & 4 & 4 & 4 & 16 \\
\hline $\begin{array}{l}\text { Jumlah siswa yang menilai guru yang sudah } \\
\text { disertifikasi }\end{array}$ & 20 & 20 & 20 & 20 & 80 \\
\hline $\begin{array}{l}\text { Jumlah siswa yang menilai guru yang belum } \\
\text { disertifikasi }\end{array}$ & 20 & 20 & 20 & 20 & 80 \\
\hline
\end{tabular}

Tabel 8 Jumlah Keseluruhan Sampel Sekolah, Guru, dan Responden Siswa

\begin{tabular}{|c|c|c|c|c|c|}
\hline \multirow{2}{*}{ Uraian } & \multicolumn{2}{|c|}{ SD } & \multicolumn{2}{|c|}{ SMP } & \multirow{2}{*}{ Total } \\
\hline & negeri & swasta & negeri & swasta & \\
\hline Jumlah sekolah sampel & 40 & 40 & 40 & 40 & 160 \\
\hline Jumlah guru yang sudah disertifikasi & 80 & 80 & 80 & 80 & 320 \\
\hline Jumlah guru yang belum disertifikasi & 80 & 80 & 80 & 80 & 320 \\
\hline $\begin{array}{l}\text { Jumlah siswa yang menilai gurunya yang sudah } \\
\text { disertifikasi }\end{array}$ & 400 & 400 & 400 & 400 & 1.600 \\
\hline $\begin{array}{l}\text { Jumlah siswa yang menilai guru yang belum } \\
\text { disertifikasi }\end{array}$ & 400 & 400 & 400 & 400 & 1.600 \\
\hline
\end{tabular}


kompetensi kepribadian dan sosial) terdiri atas 8 butir.

Sebelum digunakan untuk mengumpulkan data, kuesioner terlebih dahulu diujicobakan. Tujuan uji coba lebih diarahkan untuk mengetahui pemahaman siswa terhadap pertanyaan yang diajukan, khususnya siswa SD. Pada awalnya instrumen diujicobakan juga kepada siswa SD kelas IV. Namun karena banyak siswa SD kelas IV yang bertanya pada saat uji coba karena kurang paham terhadap pertanyaan maka diputuskan untuk tidak menggunakan siswa kelas IV sebagai responden. Selain itu keputusan untuk tidak melibatkan siswa SD kelas IV sebagai responden juga didasarkan atas pertimbangan narasumber ahli. Pertimbangan narasumber ahli yaitu bahwa siswa merupakan responden yang cukup tepat untuk menilai kompetensi gurunya karena siswa dianggap yang paling dekat dengan guru yang mengajarnya sehingga mengetahui dan dapat melakukan penilaian terhadap kemampuan dan perilaku gurunya.

Data yang terkumpul dianalisis menggunakan statistik deskriptif kuantitatif yaitu berupa proporsi siswa yang menjawab 'Ya' atas pertanyaan yang diajukan. Terdapat dua kelompok siswa yaitu kelompok yang menilai gurunya yang sudah disertifikasi dan kelompok yang menilai gurunya yang belum disertifikasi. Hipotesis awalnya adalah bahwa kompetensi guru yang sudah disertifikasi lebih baik daripada yang belum disertifikasi. Artinya proporsi siswa yang memberikan jawaban ' $Y a$ ' atas pertanyaan yang diajukan tentang kompetensi guru yang sudah disertifikasi diharapkan lebih tinggi daripada proporsi siswa yang menjawab 'Ya' atas pertanyaan yang diajukan tentang kompetensi guru yang belum disertifikasi.

\section{HASIL DAN PEMBAHASAN}

\section{Kompetensi Guru SD Negeri yang Sudah dan Belum Disertifikasi}

Tabel 9a menyajikan perbedaan persepsi siswa terhadap kompetensi guru di SD negeri antara yang sudah dan belum disertifikasi. Angka yang disajikan merupakan proporsi siswa yang menjawab 'Ya' atas pertanyaan yang diajukan kepada siswa. Tabel 9a telah menyajikan perbedaan proporsi siswa yang menilai kompetensi gurunya khusus untuk kompetensi pedagogik dan profesional. Hasil analisis adalah dari 15 butir pertanyaan yang diajukan jawaban atas empat butir pertanyaan (27\%) perbedaan proporsinya negatif. Hasil analisis jawaban untuk keempat butir pertanyaan ini menunjukkan bahwa kompetensi guru SD negeri yang belum disertifikasi sedikit lebih baik daripada yang sudah disertifikasi. Dari keempat butir pertanyaan ini perbedaan proporsi umumnya lebih kecil dari lima persen; hanya untuk satu butir pertanyaan yang perbedaan proporsinya lebih dari lima persen atau dapat dikatakan hampir tidak ada perbedaan. Sebaliknya sebanyak 11 butir pertanyaan (73\%) yang perbedaan proporsinya positif. Hasil ini menunjukkan bahwa kompetensi pedagogik dan profesional guru SD negeri yang sudah disertifikasi lebih baik daripada yang belum disertifikasi. Dari ke-11 butir pertanyaan tersebut perbedaan proporsinya umumnya lebih kecil dari atau sama dengan lima persen; hanya ada satu butir pertanyaan yang perbedaan proporsinya lebih besar dari 5\%. Dengan demikian dapat dikatakan hampir tidak ada perbedaan. Menyimak bahwa persentase butir pertanyaan yang perbedaan proporsinya positif lebih besar daripada yang perbedaan proporsinya negatif yaitu $73 \%$ berbanding $27 \%$, maka dapat dikatakan bahwa kompetensi profesional dan pedagogik guru SD negeri yang sudah disertifikasi lebih baik daripada yang belum disertifikasi.

Selanjutnya dilakukan analisis perbedaan proporsi jawaban untuk setiap butir pertanyaan untuk mengatakan sesuatu tentang perbedaan kompetensi pedagogik/profesional antara guru SD negeri yang sudah dan belum disertifikasi. Dari 15 butir pertanyaan sebanyak 13 pertanyaan $(87 \%)$ yang perbedaan proporsi jawabannya kurang dari 5\%. Hasil ini dapat memberikan gambaran bahwa tidak terdapat 
Tabel 9a Perbedaan Proporsi Siswa SD Negeri Terhadap Penilaian Kompetensi Pedagogik/Profesional Gurunya yang Sudah dan Belum Disertifikasi Per Butir Pertanyaan

\begin{tabular}{|c|c|c|c|}
\hline \multirow[t]{2}{*}{ No } & \multirow[t]{2}{*}{ Pertanyaan } & \multicolumn{2}{|c|}{$\begin{array}{l}\text { Status Kepemilikan } \\
\text { Sertifikat Pendidik }\end{array}$} \\
\hline & & Sudah & belum \\
\hline 1. & $\begin{array}{l}\text { Guru memberitahukan tujuan pembelajaran (topik yang akan } \\
\text { dipelajari) sebelum pelajaran dimulai }\end{array}$ & 0,93 & 0,94 \\
\hline 2. & $\begin{array}{l}\text { Guru mengulangi materi sebelumnya secara singkat sebelum } \\
\text { mengajarkan materi yang baru }\end{array}$ & 0,88 & 0,82 \\
\hline 3. & Guru menguasai materi pelajaran & 0,95 & 0,90 \\
\hline 4. & Guru serius pada saat mengajar & 0,95 & 0,94 \\
\hline 5. & Guru memberi cerita menarik apabila murid sudah mulai jenuh & 0,68 & 0,74 \\
\hline 6. & $\begin{array}{l}\text { Guru mengajar dengan cara yang mudah dipahami oleh sebagian } \\
\text { besar murid }\end{array}$ & 0,92 & 0,88 \\
\hline 7. & $\begin{array}{l}\text { Guru membantu murid yang belum paham terhadap materi } \\
\text { pelajaran yang diajarkan }\end{array}$ & 0,98 & 0,95 \\
\hline 8. & $\begin{array}{l}\text { Guru selalu memberikan pertanyaan kepada murid pada saat } \\
\text { mengajar }\end{array}$ & 0,97 & 0,96 \\
\hline 9. & $\begin{array}{l}\text { Guru selalu membantu murid yang tidak dapat menjawab } \\
\text { pertanyaan dengan baik }\end{array}$ & 0,91 & 0,92 \\
\hline 10. & $\begin{array}{l}\text { Guru memberi perhatian khusus pada murid yang belum } \\
\text { memahami materi pelajaran }\end{array}$ & 0,89 & 0,85 \\
\hline 11. & $\begin{array}{l}\text { Guru menjaga supaya murid tetap serius dalam mengikuti } \\
\text { pelajaran }\end{array}$ & 0,94 & 0,96 \\
\hline 12. & $\begin{array}{l}\text { Guru memberikan pujian kepada murid yang mengerjakan } \\
\text { tugasnya dengan baik }\end{array}$ & 0,90 & 0,86 \\
\hline 13. & Guru datang tepat waktu pada saat pelajaran dimulai & 0,83 & 0,83 \\
\hline 14. & Guru tidak meninggalkan kelas sebelum jam pelajaran selesai & 0,71 & 0,67 \\
\hline 15. & $\begin{array}{l}\text { Guru mengembalikan tugas di kelas yang sudah dikerjakan murid } \\
\text { setelah dikoreksi }\end{array}$ & 0,95 & 0,92 \\
\hline
\end{tabular}

perbedaan kompetensi pedagogik/profesional yang berarti antara guru SD negeri yang sudah dan belum disertifikasi.

Tabel 9b telah menyajikan perbedaan proporsi siswa yang menilai kompetensi gurunya khusus untuk kompetensi kepribadian dan sosial. Hasil analisisnya: dari delapan butir pertanyaan yang diajukan jawaban atas empat butir pertanyaan $(50 \%)$ perbedaan proporsinya negatif. Hasil analisis jawaban untuk keempat butir pertanyaan ini menunjukkan bahwa kompetensi kepribadian dan sosial guru SD negeri yang belum disertifikasi sedikit lebih baik daripada yang sudah disertifikasi. Dari keempat butir pertanyaan ini perbedaan proporsinya umumnya lebih kecil dari 5\%; hanya untuk satu butir pertanyaan yang perbedaan proporsinya lebih dari 5\%. Dengan demikian dapat dikatakan hampir tidak ada perbedaan. Sebaliknya juga sebanyak 4 butir pertanyaan (50\%) yang perbedaan proporsinya positif. Hasil ini menunjukkan bahwa kompetensi kepribadian dan sosial guru SD negeri yang sudah disertifikasi lebih baik daripada yang belum disertifikasi. Dari keempat butir pertanyaan tersebut perbedaan proporsinya umumnya lebih kecil dari $5 \%$; hanya ada satu butir pertanyaan yang perbedaan proporsinya lebih besar dari 5\%. Dengan demikian dapat dikatakan hampir tidak ada perbedaan. Menyimak bahwa persentase butir pertanyaan yang perbedaan proporsinya positif sama besar dengan yang perbedaan proporsinya negatif yaitu $50 \%$ berbanding $50 \%$, maka dapat dikatakan bahwa kompetensi kepribadian dan sosial guru SD negeri yang sudah disertifikasi tidak berbeda dengan yang belum disertifikasi.

Selanjutnya dilakukan analisis perbedaan proporsi jawaban untuk setiap butir pertanyaan 
Tabel 9b Perbedaan Proporsi Siswa SD Negeri Terhadap Penilaian Kompetensi Kepribadian/Sosial Gurunya yang Sudah dan Belum Disertifikasi Per Butir Pertanyaan

\begin{tabular}{|c|c|c|c|c|}
\hline \multirow[t]{2}{*}{ No } & \multirow[t]{2}{*}{ Pertanyaan } & \multicolumn{2}{|c|}{$\begin{array}{l}\text { Status Kepemilikan } \\
\text { Sertifikat Pendidik }\end{array}$} & \multirow{2}{*}{$\begin{array}{c}\text { Selisih } \\
\text { Pro- } \\
\text { porsi }\end{array}$} \\
\hline & & Sudah & belum & \\
\hline 1. & $\begin{array}{l}\text { Saya merasa bersalah bila tidak melaksanakan tugas yang } \\
\text { diberikan oleh guru. }\end{array}$ & 0,98 & 0,97 & 0,01 \\
\hline 2. & Saya dapat bersenda gurau bersama guru & 0,54 & 0,60 & $-0,06$ \\
\hline 3. & $\begin{array}{l}\text { Saya dapat berkonsentrasi pada saat guru menerangkan materi } \\
\text { pelajaran }\end{array}$ & 0,96 & 0,96 & 0,00 \\
\hline 4. & $\begin{array}{l}\text { Saya mendapat teguran dari guru apabila saya melakukan } \\
\text { kesalahan. }\end{array}$ & 0,95 & 0,99 & $-0,04$ \\
\hline 5. & Saya hormat terhadap guru & 0,98 & 0,99 & $-0,02$ \\
\hline 6. & Guru minta maaf kepada murid apabila melakukan kesalahan & 0,86 & 0,86 & 0,00 \\
\hline 7. & Saya merasa kehilangan apabila guru berhalangan mengajar & 0,92 & 0,85 & 0,07 \\
\hline 8. & Guru tidak berlaku kasar pada murid & 0,88 & 0,90 & $-0,02$ \\
\hline
\end{tabular}

untuk mengatakan sesuatu tentang perbedaan kompetensi sosial/kepribadian antara guru SD negeri yang sudah dan belum disertifikasi. Dari 8 butir pertanyaan, sebanyak 6 pertanyaan (75\%) perbedaan proporsi jawabannya kurang dari lima persen. Hasil ini dapat memberikan gambaran bahwa tidak terdapat perbedaan kompetensi sosial/kepribadian yang berarti antara guru SD negeri yang sudah dan belum disertifikasi.

Untuk melihat apakah terdapat perbedaan kompetensi secara umum antara guru SD negeri yang sudah dan belum disertifikasi, dikalkulasi selisih proporsi siswa yang menjawab 'Ya' atas pertanyaan yang diajukan. Dalam Tabel 9a dan 9 b terlihat bahwa dari 23 pertanyaan hanya ada delapan pertanyaan (35\%) yang perbedaan proporsi jawabannya negatif. Perbedaan proporsi negatif menunjukkan bahwa kompetensi guru SD negeri yang belum disertifikasi lebih baik daripada yang sudah disertifikasi. Sebaliknya terdapat 15 pertanyaan (65\%) yang perbedaan proporsi jawabannya positif. Perbedaan proporsi positif ini menunjukkan bahwa kompetensi guru SD negeri yang sudah disertifikasi menurut persepsi siswa lebih baik daripada guru yang belum disertifikasi. Menyimak bahwa persentase butir pertanyaan yang perbedaan proporsi jawabannya positif lebih besar daripada yang perbedaan proporsi jawabannya negatif yaitu $65 \%$ berbanding $35 \%$, maka dapat dikatakan bahwa kompetensi guru SD negeri yang sudah disertifikasi lebih baik daripada yang belum disertifikasi.

\section{Kompetensi Guru SD Swasta yang Sudah dan Belum Disertifikasi}

Tabel 10a menyajikan perbedaan persepsi siswa terhadap kompetensi guru di SD swasta antara yang sudah dan yang belum disertifikasi. Angka yang disajikan merupakan proporsi siswa yang menjawab ' $Y a$ ' atas petanyaan yang diajukan kepada siswa. Tabel $10 a$ telah menyajikan perbedaan proporsi siswa yang menilai kompetensi gurunya khusus untuk kompetensi pedagogik dan profesional. Hasil analisisnya adalah dari 15 butir pertanyaan yang diajukan jawaban atas enam butir pertanyaan (40\%) perbedaan proporsinya negatif. Hasil analisis jawaban untuk keenam butir pertanyaan ini menunjukkan bahwa kompetensi pedagogik dan profesional guru SD swasta yang belum disertifikasi sedikit lebih baik daripada yang sudah disertifikasi. Dari keenam butir pertanyaan ini perbedaan proporsinya umumnya lebih kecil dari lima persen; hanya untuk satu butir pertanyaan yang perbedaan proporsinya lebih dari 5\%. Dengan demikian dapat dikatakan hampir tidak ada perbedaan. Sebaliknya sebanyak 9 butir pertanyaan (60\%) yang perbedaan proporsinya positif. Hasil ini menunjukkan bahwa kompetensi pedagogik dan profesional 
Tabel 10a Perbedaan Proporsi Siswa SD Swasta Terhadap Penilaian Kompetensi Pedagogik/ Profesional Gurunya yang Sudah dan Belum Disertifikasi Per Butir Pertanyaan

\begin{tabular}{|c|c|c|c|}
\hline \multirow{2}{*}{ No } & \multirow{2}{*}{ Pertanyaan } & \multicolumn{2}{|c|}{$\begin{array}{l}\text { Status Kepemilikan } \\
\text { Sertifikat Pendidik }\end{array}$} \\
\hline & & Sudah & belum \\
\hline 1. & $\begin{array}{l}\text { Guru memberitahukan tujuan pembelajaran (topik yang akan } \\
\text { dipelajari) sebelum pelajaran dimulai }\end{array}$ & 0,89 & 0,86 \\
\hline 2. & $\begin{array}{l}\text { Guru mengulangi materi sebelumnya secara singkat sebelum } \\
\text { mengajarkan materi yang baru }\end{array}$ & 0,88 & 0,79 \\
\hline 3. & Guru menguasai materi pelajaran & 0,91 & 0,94 \\
\hline 4. & Guru serius pada saat mengajar & 0,95 & 0,95 \\
\hline 5. & Guru memberi cerita menarik apabila murid sudah mulai jenuh & 0,63 & 0,59 \\
\hline 6. & $\begin{array}{l}\text { Guru mengajar dengan cara yang mudah dipahami oleh sebagian } \\
\text { besar murid }\end{array}$ & 0,92 & 0,94 \\
\hline 7. & $\begin{array}{l}\text { Guru membantu murid yang belum paham terhadap materi } \\
\text { pelajaran yang diajarkan }\end{array}$ & 0,97 & 0,95 \\
\hline 8. & $\begin{array}{l}\text { Guru selalu memberikan pertanyaan kepada murid pada saat } \\
\text { mengajar }\end{array}$ & 0,95 & 0,95 \\
\hline 9. & $\begin{array}{l}\text { Guru selalu membantu murid yang tidak dapat menjawab } \\
\text { pertanyaan dengan baik }\end{array}$ & 0,91 & 0,92 \\
\hline 10. & $\begin{array}{l}\text { Guru memberi perhatian khusus pada murid yang belum } \\
\text { memahami materi pelajaran }\end{array}$ & 0,86 & 0,84 \\
\hline 11. & $\begin{array}{l}\text { Guru menjaga supaya murid tetap serius dalam mengikuti } \\
\text { pelajaran }\end{array}$ & 0,93 & 0,94 \\
\hline 12. & $\begin{array}{l}\text { Guru memberikan pujian kepada murid yang mengerjakan } \\
\text { tugasnya dengan baik }\end{array}$ & 0,81 & 0,81 \\
\hline 13. & Guru datang tepat waktu pada saat pelajaran dimulai & 0,78 & 0,79 \\
\hline 14. & Guru tidak meninggalkan kelas sebelum jam pelajaran selesai & 0,71 & 0,86 \\
\hline 15. & $\begin{array}{l}\text { Guru mengembalikan tugas di kelas yang sudah dikerjakan murid } \\
\text { setelah dikoreksi }\end{array}$ & 0,93 & 0,91 \\
\hline
\end{tabular}

guru SD swasta yang sudah disertifikasi lebih baik daripada yang belum disertifikasi. Dari kesembilan butir pertanyaan tersebut perbedaan proporsinya umumnya lebih kecil dari 5\%; hanya ada satu butir pertanyaan yang perbedaan proporsinya lebih besar dari 5\%. Dengan demikian dapat dikatakan hampir tidak ada perbedaan. Mengingat bahwa persentase butir pertanyaan yang perbedaan proporsinya positif lebih besar daripada yang perbedaan proporsinya negatif yaitu $60 \%$ berbanding $40 \%$, maka dapat dikatakan bahwa kompetensi profesional dan pedagogik guru SD swasta yang sudah disertifikasi lebih baik daripada yang belum disertifikasi.

Selanjutnya dilakukan analisis perbedaan proporsi jawaban untuk setiap butir pertanyaan untuk mengatakan sesuatu tentang perbedaan kompetensi pedagogis/profesional antara guru SD swasta yang sudah dan belum disertifikasi.
Dari 15 butir pertanyaan sebanyak 13 pertanyaan ( $87 \%$ ) yang perbedaan proporsi jawabannya kurang dari 5\%.

Hasil ini dapat memberikan gambaran bahwa tidak terdapat perbedaan kompetensi pedagogis/profesional yang berarti antara guru SD swasta yang sudah dan belum disertifikasi.

Dalam Tabel 10b disajikan perbedaan proporsi siswa yang menilai kompetensi gurunya khusus untuk kompetensi kepribadian dan sosial. Tabel 10b telah menyajikan perbedaan proporsi siswa yang menilai kompetensi gurunya khusus untuk kompetensi kepribadian dan sosial. Hasil analisisnya: dari delapan butir pertanyaan yang diajukan jawaban atas empat butir pertanyaan (50\%) perbedaan proporsinya negatif. Hasil analisis jawaban untuk keempat butir pertanyaan ini menunjukkan bahwa kompetensi guru yang belum disertifikasi sedikit lebih baik daripada yang sudah disertifikasi. Dari keempat butir 
Tabel 10b Perbedaan Proporsi Siswa SD Swasta Terhadap Penilaian Kompetensi Kepribadian/Sosial Gurunya yang Sudah dan Belum Disertifikasi Per Item Pertanyaan

\begin{tabular}{|c|c|c|c|c|}
\hline \multirow{2}{*}{ No } & \multirow{2}{*}{ Pertanyaan } & \multicolumn{2}{|c|}{$\begin{array}{l}\text { Status Kepemilikan } \\
\text { Sertifikat Pendidik }\end{array}$} & \multirow{2}{*}{$\begin{array}{c}\text { Selisih } \\
\text { Pro- } \\
\text { porsi }\end{array}$} \\
\hline & & Sudah & belum & \\
\hline 1. & $\begin{array}{l}\text { Saya merasa bersalah bila tidak melaksanakan tugas yang } \\
\text { diberikan oleh guru }\end{array}$ & 0,94 & 0,97 & $-0,03$ \\
\hline 2. & Saya dapat bersenda gurau bersama guru & 0,62 & 0,63 & $-0,01$ \\
\hline 3. & $\begin{array}{l}\text { Saya dapat berkonsentrasi pada saat guru menerangkan } \\
\text { materi pelajaran }\end{array}$ & 0,97 & 0,96 & 0,01 \\
\hline 4. & $\begin{array}{l}\text { Saya mendapat teguran dari guru apabila saya melakukan } \\
\text { kesalahan. }\end{array}$ & 0,94 & 0,95 & $-0,02$ \\
\hline 5. & Saya hormat terhadap guru & 0,99 & 0,99 & 0,00 \\
\hline 6. & $\begin{array}{l}\text { Guru minta maaf kepada murid apabila melakukan } \\
\text { kesalahan }\end{array}$ & 0,86 & 0,86 & 0,00 \\
\hline 7. & $\begin{array}{l}\text { Saya merasa kehilangan apabila guru berhalangan } \\
\text { mengajar }\end{array}$ & 0,84 & 0,87 & $-0,02$ \\
\hline 8. & Guru tidak berlaku kasar pada murid & 0,86 & 0,82 & 0,04 \\
\hline
\end{tabular}

pertanyaan ini perbedaan proporsinya lebih kecil dari 5\%. Dengan demikian dapat dikatakan hampir tidak ada perbedaan. Sebaliknya juga sebanyak 4 butir pertanyaan (50\%) yang perbedaan proporsi jawabannya positif. Hasil ini menunjukkan bahwa kompetensi kepribadian dan sosial guru SD swasta yang sudah disertifikasi lebih baik daripada yang belum disertifikasi. Dari keempat butir pertanyaan tersebut perbedaan proporsinya lebih kecil dari 5\%. Dengan demikian dapat dikatakan hampir tidak ada perbedaan. Persentase butir pertanyaan yang perbedaan proporsinya positif sama besar dengan yang perbedaan proporsinya negatif yaitu $50 \%$ berbanding 50\%, maka dapat dikatakan bahwa kompetensi kepribadian dan sosial guru SD swasta yang sudah disertifikasi tidak berbeda dengan yang belum disertifikasi.

Selanjutnya dilakukan analisis perbedaan proporsi jawaban untuk setiap butir pertanyaan untuk mengatakan sesuatu tentang perbedaan kompetensi sosial/kepribadian antara guru SD swasta yang sudah dan belum disertifikasi. Dari 8 butir pertanyaan, seluruhnya (100\%) perbedaan proporsi jawabannya kurang dari lima persen. Hasil ini memberikan gambaran bahwa tidak terdapat perbedaan kompetensi sosial/ kepribadian yang berarti antara guru SD swasta yang sudah dan belum disertifikasi.
Untuk melihat apakah terdapat perbedaan kompetensi secara umum antara guru SD swasta yang sudah dan belum disertifikasi, dikalkulasi selisih proporsi siswa yang menjawab 'Ya' atas pertanyaan yang diajukan. Dalam Tabel 10a dan $10 \mathrm{~b}$ terlihat bahwa dari 23 pertanyaan hanya ada sepuluh pertanyaan ( $43 \%$ ) yang perbedaan proporsinya negatif. Perbedaan proporsi negatif menunjukkan bahwa kompetensi guru SD swasta yang belum disertifikasi lebih baik daripada yang sudah disertifikasi. Sebaliknya terdapat 13 pertanyaan (57\%) yang perbedaan proporsinya positif. Perbedaan proporsi positif ini menunjukkan bahwa kompetensi guru SD swasta yang sudah disertifikasi menurut persepsi siswa lebih baik daripada guru yang belum disertifikasi. Persentase butir pertanyaan yang perbedaan proporsi jawabannya positif lebih besar daripada yang perbedaan proporsi jawabannya negatif yaitu $57 \%$ berbanding $43 \%$, maka dapat dikatakan bahwa kompetensi guru SD swasta yang sudah disertifikasi lebih baik daripada yang belum disertifikasi.

\section{Kompetensi Guru SMP Negeri yang Sudah dan Belum Disertifikasi}

Tabel 11a menyajikan perbedaan persepsi siswa terhadap kompetensi guru di SMP negeri antara yang sudah dan belum disertifikasi. Angka yang 
disajikan merupakan proporsi siswa yang menjawab 'Ya' atas petanyaan yang diajukan kepada siswa.

Tabel 11a telah menyajikan perbedaan proporsi siswa yang menilai kompetensi gurunya khusus untuk kompetensi pedagogik dan profesional. Hasil analisisnya dari 15 butir pertanyaan yang diajukan jawaban atas sembilan butir pertanyaan $(60 \%)$ perbedaan proporsinya negatif. Hasil analisis jawaban untuk kesembilan butir pertanyaan ini menunjukkan bahwa kompetensi guru SMP negeri yang belum disertifikasi sedikit lebih baik daripada yang sudah disertifikasi. Dari kesembilan butir pertanyaan ini perbedaan proporsinya umumnya lebih kecil atau sama dengan lima persen. Dengan demikian dapat dikatakan hampir tidak ada perbedaan. Sebaliknya sebanyak 6 butir pertanyaan $(40 \%)$ yang perbedaan proporsinya positif. Hasil ini menunjukkan bahwa kompetensi pedagogik dan profesional guru SMP negeri yang sudah disertifikasi lebih baik daripada yang belum disertifikasi. Dari keenam butir pertanyaan tersebut perbedaan proporsi jawabannya lebih kecil dari lima persen. Dengan demikian dapat dikatakan hampir tidak ada perbedaan. Menyimak bahwa persentase butir pertanyaan yang perbedaan proporsi jawabannya negatif lebih besar daripada yang perbedaan proporsi jawabannya positif yaitu $60 \%$ berbanding $40 \%$, maka dapat dikatakan bahwa kompetensi profesional dan pedagogik guru SMP negeri yang belum disertifikasi lebih baik daripada yang sudah disertifikasi.

Selanjutnya dilakukan analisis perbedaan proporsi jawaban untuk setiap butir pertanyaan untuk mengatakan sesuatu tentang perbedaan kompetensi pedagogik/profesional antara guru SMP negeri yang sudah dan belum disertifikasi. Dari 15 butir pertanyaan, seluruhnya (100\%)

Tabel 11a Perbedaan Proporsi Siswa SMP Negeri Terhadap Penilaian Kompetensi Pedagogis/ Profesional Gurunya yang Sudah dan Belum Disertifikasi Per Butir Pertanyaan

\begin{tabular}{|c|c|c|c|c|}
\hline \multirow{2}{*}{ No } & \multirow{2}{*}{ Pertanyaan } & \multicolumn{2}{|c|}{$\begin{array}{l}\text { Status Kepemilikan } \\
\text { Sertifikat Pendidik }\end{array}$} & \multirow{2}{*}{$\begin{array}{c}\text { Selisih } \\
\text { Pro- } \\
\text { porsi }\end{array}$} \\
\hline & & Sudah & belum & \\
\hline 1. & $\begin{array}{l}\text { Guru memberitahukan tujuan pembelajaran (topik yang akan } \\
\text { dipelajari) sebelum pelajaran dimulai }\end{array}$ & 0,95 & 0,98 & $-0,03$ \\
\hline 2. & $\begin{array}{l}\text { Guru mengulangi materi sebelumnya secara singkat sebelum } \\
\text { mengajarkan materi yang baru }\end{array}$ & 0,91 & 0,95 & $-0,04$ \\
\hline 3. & Guru menguasai materi pelajaran & 0,97 & 0,98 & $-0,01$ \\
\hline 4. & Guru serius pada saat mengajar & 0,96 & 0,95 & 0,00 \\
\hline 5. & Guru memberi cerita menarik apabila murid sudah mulai jenuh & 0,75 & 0,71 & 0,04 \\
\hline 6. & $\begin{array}{l}\text { Guru mengajar dengan cara yang mudah dipahami oleh sebagian } \\
\text { besar murid }\end{array}$ & 0,95 & 0,92 & 0,03 \\
\hline 7. & $\begin{array}{l}\text { Guru membantu murid yang belum paham terhadap materi } \\
\text { pelajaran yang diajarkan }\end{array}$ & 0,96 & 0,96 & 0,00 \\
\hline 8. & $\begin{array}{l}\text { Guru selalu memberikan pertanyaan kepada murid pada saat } \\
\text { mengajar }\end{array}$ & 0,90 & 0,93 & $-0,03$ \\
\hline 9. & $\begin{array}{l}\text { Guru selalu membantu murid yang tidak dapat menjawab } \\
\text { pertanyaan dengan baik }\end{array}$ & 0,91 & 0,93 & $-0,02$ \\
\hline 10. & $\begin{array}{l}\text { Guru memberi perhatian khusus pada murid yang belum } \\
\text { memahami materi pelajaran }\end{array}$ & 0,80 & 0,78 & 0,02 \\
\hline 11. & $\begin{array}{l}\text { Guru menjaga supaya murid tetap serius dalam mengikuti } \\
\text { pelajaran }\end{array}$ & 0,96 & 0,95 & 0,01 \\
\hline 12. & $\begin{array}{l}\text { Guru memberikan pujian kepada murid yang mengerjakan } \\
\text { tugasnya dengan baik }\end{array}$ & 0,82 & 0,86 & $-0,04$ \\
\hline 13. & Guru datang tepat waktu pada saat pelajaran dimulai & 0,84 & 0,89 & $-0,05$ \\
\hline 14. & Guru tidak meninggalkan kelas sebelum jam pelajaran selesai & 0,88 & 0,91 & $-0,03$ \\
\hline 15. & $\begin{array}{l}\text { Guru mengembalikan tugas di kelas yang sudah dikerjakan murid } \\
\text { setelah dikoreksi }\end{array}$ & 0,92 & 0,95 & $-0,03$ \\
\hline
\end{tabular}


perbedaan proporsi jawabannya kurang dari atau sama dengan lima persen. Hasil ini memberikan gambaran bahwa tidak terdapat perbedaan kompetensi pedagogik/profesional yang berarti antara guru SMP negeri yang sudah dan belum disertifikasi.

Tabel 11b menyajikan perbedaan proporsi siswa yang menilai kompetensi gurunya khusus untuk kompetensi kepribadian dan sosial. Hasil analisis dari delapan butir pertanyaan yang diajukan jawaban atas empat butir pertanyaan (50\%) perbedaan proporsinya negatif. Hasil analisis jawaban untuk keempat butir pertanyaan ini menunjukkan bahwa kompetensi kepribadian dan sosial guru SMP negeri yang belum disertifikasi sedikit lebih baik daripada yang sudah disertifikasi. Dari keempat butir pertanyaan ini perbedaan proporsinya lebih kecil dari 5\%. Dengan demikian dapat dikatakan hampir tidak ada perbedaan. Sebaliknya juga sebanyak 4 butir pertanyaan ( $50 \%$ ) yang perbedaan proporsi jawabannya positif. Hasil ini menunjukkan bahwa kompetensi kepribadian dan sosial guru SMP negeri yang sudah disertifikasi lebih baik daripada yang belum disertifikasi. Dari keempat butir pertanyaan tersebut perbedaan proporsinya lebih kecil dari lima persen. Dengan demikian dapat dikatakan hampir tidak ada perbedaan. Menyimak bahwa persentase butir pertanyaan yang perbedaan proporsi ja- wabannya positif sama besar dengan yang perbedaan proporsi jawabannya negatif yaitu $50 \%$ berbanding 50\%, maka dapat dikatakan bahwa kompetensi kepribadian dan sosial guru SMP negeri yang sudah disertifikasi tidak berbeda dengan yang belum disertifikasi.

Selanjutnya dilakukan analisis perbedaan proporsi jawaban untuk setiap butir pertanyaan untuk mengatakan sesuatu tentang perbedaan kompetensi sosial/kepribadian antara guru SMP negeri yang sudah dan belum disertifikasi. Dari 8 butir pertanyaan, seluruhnya (100\%) perbedaan proporsi jawabannya kurang dari lima persen. Hasil ini memberikan gambaran bahwa tidak terdapat perbedaan kompetensi sosial/ kepribadian yang berarti antara guru SMP negeri yang sudah dan belum disertifikasi.

Untuk melihat apakah terdapat perbedaan kompetensi secara umum antara guru SMP negeri yang sudah dan belum disertifikasi, dikalkulasi selisih proporsi siswa yang menjawab 'Ya' atas pertanyaan yang diajukan. Dalam Tabel 11a dan 11b terlihat bahwa dari 23 pertanyaan ada 13 pertanyaan (57\%) yang perbedaan proporsi jawabannya negatif. Perbedaan proporsi negatif menunjukkan bahwa kompetensi guru SMP negeri yang belum disertifikasi lebih baik daripada yang sudah disertifikasi. Sebaliknya terdapat 10 pertanyaan (43\%) yang perbedaan proporsi jawabannya positif. Perbedaan proporsi

Tabel 11b Perbedaan Proporsi Siswa SMP Negeri Terhadap Penilaian Kompetensi Kepribadian/Sosial Gurunya yang Sudah dan Belum Disertifikasi Per Butir Pertanyaan

\begin{tabular}{|c|c|c|c|c|}
\hline \multirow[t]{2}{*}{ No } & \multirow[t]{2}{*}{ Pertanyaan } & \multicolumn{2}{|c|}{$\begin{array}{l}\text { Status Kepemilikan } \\
\text { Sertifikat Pendidik }\end{array}$} & \multirow{2}{*}{$\begin{array}{c}\text { Selisih } \\
\text { Pro- } \\
\text { porsi }\end{array}$} \\
\hline & & Sudah & belum & \\
\hline 1. & $\begin{array}{l}\text { Saya merasa bersalah bila tidak melaksanakan tugas yang } \\
\text { diberikan oleh guru. }\end{array}$ & 0,99 & 1,00 & $-0,01$ \\
\hline 2. & Saya dapat bersenda gurau bersama guru & 0,67 & 0,71 & $-0,04$ \\
\hline 3. & $\begin{array}{l}\text { Saya dapat berkonsentrasi pada saat guru menerangkan } \\
\text { materi pelajaran }\end{array}$ & 0,95 & 0,95 & 0,00 \\
\hline 4. & $\begin{array}{l}\text { Saya mendapat teguran dari guru apabila saya melakukan } \\
\text { kesalahan. }\end{array}$ & 0,99 & 0,97 & 0,01 \\
\hline 5. & Saya hormat terhadap guru & 0,99 & 1,00 & $-0,01$ \\
\hline 6. & Guru minta maaf kepada murid apabila melakukan kesalahan & 0,92 & 0,89 & 0,02 \\
\hline 7. & Saya merasa kehilangan apabila guru berhalangan mengajar & 0,90 & 0,89 & 0,01 \\
\hline 8. & Guru tidak berlaku kasar pada murid & 0,94 & 0,97 & $-0,03$ \\
\hline
\end{tabular}


positif ini menunjukkan bahwa kompetensi guru SMP negeri yang sudah disertifikasi menurut persepsi siswa lebih baik daripada guru yang belum disertifikasi. Menyimak bahwa persentase butir pertanyaan yang perbedaan proporsi jawabannya negatif lebih besar daripada yang perbedaan proporsi jawabannya positif yaitu $57 \%$ berbanding $43 \%$, maka dapat dikatakan bahwa kompetensi guru SMP negeri yang belum disertifikasi lebih baik daripada yang sudah disertifikasi.

\section{Kompetensi Guru SMP Swasta yang Sudah dan Belum Disertifikasi}

Tabel 12a menyajikan perbedaan persepsi siswa terhadap kompetensi guru di SMP swasta antara yang sudah dan belum disertifikasi. Angka yang disajikan merupakan proporsi siswa yang menjawab ' $Y a$ ' atas petanyaan yang diajukan kepada siswa.
Tabel 12 a telah menyajikan perbedaan proporsi siswa yang menilai kompetensi gurunya khusus untuk kompetensi pedagogik dan profesional. Hasil analisis dari 15 butir pertanyaan yang diajukan jawaban atas 11 butir pertanyaan $(73 \%)$ perbedaan proporsinya negatif. Hasil analisis jawaban untuk ke-11 butir pertanyaan ini menunjukkan bahwa kompetensi pedagogik dan profesional guru SMP swasta yang belum disertifikasi sedikit lebih baik daripada yang sudah disertifikasi. Dari ke-11 butir pertanyaan ini perbedaan proporsi jawabannya umumnya lebih kecil dari lima persen; hanya untuk satu butir pertanyaan yang perbedaan proporsi jawabannya lebih dari lima persen. Dengan demikian dapat dikatakan hampir tidak ada perbedaan. Sebaliknya sebanyak 4 butir pertanyaan $(27 \%)$ yang perbedaan proporsi jawabannya positif. Hasil ini menunjukkan bahwa kompetensi pedagogik dan profesional guru SMP

Tabel 12a Perbedaan Proporsi Siswa SMP Swasta Terhadap Penilaian Kompetensi pedagogik/ profesional Gurunya yang Sudah dan Belum Disertifikasi Per Butir Pertanyaan

\begin{tabular}{|c|c|c|c|c|}
\hline \multirow[t]{2}{*}{ No } & \multirow{2}{*}{ Pertanyaan } & \multicolumn{2}{|c|}{$\begin{array}{l}\text { Status Kepemilikan } \\
\text { Sertifikat Pendidik }\end{array}$} & \multirow{2}{*}{$\begin{array}{c}\text { Selisih } \\
\text { Pro- } \\
\text { porsi }\end{array}$} \\
\hline & & Sudah & belum & \\
\hline 1. & $\begin{array}{l}\text { Guru memberitahukan tujuan pembelajaran (topik yang akan } \\
\text { dipelajari) sebelum pelajaran dimulai }\end{array}$ & 0,92 & 0,96 & $-0,04$ \\
\hline 2. & $\begin{array}{l}\text { Guru mengulangi materi sebelumnya secara singkat sebelum } \\
\text { mengajarkan materi yang baru }\end{array}$ & 0,88 & 0,92 & $-0,04$ \\
\hline 3. & Guru menguasai materi pelajaran & 0,98 & 0,97 & 0,01 \\
\hline 4. & Guru serius pada saat mengajar & 0,89 & 0,93 & $-0,04$ \\
\hline 5. & Guru memberi cerita menarik apabila murid sudah mulai jenuh & 0,68 & 0,73 & $-0,05$ \\
\hline 6. & $\begin{array}{l}\text { Guru mengajar dengan cara yang mudah dipahami oleh sebagian } \\
\text { besar murid }\end{array}$ & 0,92 & 0,87 & 0,05 \\
\hline 7. & $\begin{array}{l}\text { Guru membantu murid yang belum paham terhadap materi } \\
\text { pelajaran yang diajarkan }\end{array}$ & 0,96 & 0,99 & $-0,04$ \\
\hline 8. & $\begin{array}{l}\text { Guru selalu memberikan pertanyaan kepada murid pada saat } \\
\text { mengajar }\end{array}$ & 0,93 & 0,96 & $-0,03$ \\
\hline 9. & $\begin{array}{l}\text { Guru selalu membantu murid yang tidak dapat menjawab } \\
\text { pertanyaan dengan baik }\end{array}$ & 0,90 & 0,91 & $-0,02$ \\
\hline 10. & $\begin{array}{l}\text { Guru memberi perhatian khusus pada murid yang belum } \\
\text { memahami materi pelajaran }\end{array}$ & 0,74 & 0,79 & $-0,05$ \\
\hline 11. & $\begin{array}{l}\text { Guru menjaga supaya murid tetap serius dalam mengikuti } \\
\text { pelajaran }\end{array}$ & 0,95 & 0,92 & 0,03 \\
\hline 12. & $\begin{array}{l}\text { Guru memberikan pujian kepada murid yang mengerjakan } \\
\text { tugasnya dengan baik }\end{array}$ & 0,75 & 0,81 & $-0,06$ \\
\hline 13. & Guru datang tepat waktu pada saat pelajaran dimulai & 0,81 & 0,84 & $-0,03$ \\
\hline 14. & Guru tidak meninggalkan kelas sebelum jam pelajaran selesai & 0,88 & 0,87 & 0,01 \\
\hline 15. & $\begin{array}{l}\text { Guru mengembalikan tugas di kelas yang sudah dikerjakan murid } \\
\text { setelah dikoreksi }\end{array}$ & 0,90 & 0,91 & $-0,02$ \\
\hline
\end{tabular}


swasta yang sudah disertifikasi lebih baik daripada yang belum disertifikasi. Dari keempat butir pertanyaan tersebut perbedaan proporsi jawabannya lebih kecil atau sama dengan lima persen. Dengan demikian dapat dikatakan hampir tidak ada perbedaan. Menyimak bahwa persentase butir pertanyaan yang perbedaan proporsi jawabannya negatif lebih besar daripada yang perbedaan proporsi jawabannya positif yaitu $73 \%$ berbanding $27 \%$, maka dapat dikatakan bahwa kompetensi profesional dan pedagogik guru SMP swasta yang belum disertifikasi lebih baik daripada yang sudah disertifikasi.

Selanjutnya dilakukan analisis perbedaan proporsi jawaban untuk setiap butir pertanyaan untuk mengatakan sesuatu tentang perbedaan kompetensi pedagogik/profesional antara guru SMP swasta yang sudah dan belum disertifikasi. Dari 15 butir pertanyaan, sebanyak 14 pertanyaan (93\%) yang perbedaan proporsi jawabannya kurang dari atau sama dengan lima persen. Hasil ini dapat memberikan gambaran bahwa tidak terdapat perbedaan kompetensi pedagogik/profesional yang berarti antara guru SMP swasta yang sudah dan belum disertifikasi.

Tabel 12b menyajikan perbedaan proporsi siswa yang menilai kompetensi gurunya khusus untuk kompetensi kepribadian dan sosial. Hasil analisis dari delapan butir pertanyaan yang diajukan jawaban atas lima butir pertanyaan
(63\%) perbedaan proporsinya negatif. Hasil analisis jawaban untuk kelima butir pertanyaan ini menunjukkan bahwa kompetensi kepribadian dan sosial guru SMP swasta yang belum disertifikasi sedikit lebih baik daripada yang sudah disertifikasi. Dari kelima butir pertanyaan ini perbedaan proporsi jawabannya umumnya lebih kecil dari lima persen, hanya untuk satu butir pertanyaan yang perbedaan proporsinya lebih dari lima persen. Dengan demikian dapat dikatakan hampir tidak ada perbedaan. Sebaliknya sebanyak 3 butir pertanyaan (37\%) yang perbedaan proporsinya positif. Hasil ini menunjukkan bahwa kompetensi kepribadian dan sosial guru SMP swasta yang sudah disertifikasi lebih baik daripada yang belum disertifikasi. Dari ketiga butir pertanyaan tersebut perbedaan proporsinya lebih kecil dari atau sama dengan lima persen. Dengan demikian dapat dikatakan hampir tidak ada perbedaan. Menyimak bahwa persentase butir pertanyaan yang perbedaan proporsi jawab-annya negatif lebih besar daripada yang perbedaan proporsi jawabannya positif yaitu $63 \%$ berbanding $37 \%$, maka dapat dikatakan bahwa kompetensi kepribadian dan sosial guru SMP swasta yang belum disertifikasi lebih baik daripada yang sudah disertifikasi.

Selanjutnya dilakukan analisis perbedaan proporsi jawaban untuk setiap butir pertanyaan untuk mengatakan sesuatu tentang perbedaan kompetensi sosial/kepribadian antara guru SMP

Tabel 12b Perbedaan Proporsi Siswa SMP Swasta Terhadap Penilaian Kompetensi Kepribadian/ Sosial Gurunya yang Sudah dan Belum Disertifikasi Per Butir Pertanyaan

\begin{tabular}{|c|c|c|c|c|}
\hline \multirow[t]{2}{*}{ No } & \multirow{2}{*}{ Pertanyaan } & \multicolumn{2}{|c|}{$\begin{array}{l}\text { Status Kepemilikan } \\
\text { Sertifikat Pendidik }\end{array}$} & \multirow{2}{*}{$\begin{array}{c}\text { Selisih } \\
\text { Pro- } \\
\text { porsi }\end{array}$} \\
\hline & & Sudah & belum & \\
\hline 1. & $\begin{array}{l}\text { Saya merasa bersalah bila tidak melaksanakan tugas yang } \\
\text { diberikan oleh guru. }\end{array}$ & 0,99 & 0,99 & $-0,01$ \\
\hline 2. & Saya dapat bersenda gurau bersama guru & 0,74 & 0,69 & 0,05 \\
\hline 3. & $\begin{array}{l}\text { Saya dapat berkonsentrasi pada saat guru menerangkan } \\
\text { materi pelajaran }\end{array}$ & 0,93 & 0,95 & $-0,03$ \\
\hline 4. & $\begin{array}{l}\text { Saya mendapat teguran dari guru apabila saya melakukan } \\
\text { kesalahan. }\end{array}$ & 0,97 & 0,97 & 0,00 \\
\hline 5. & Saya hormat terhadap guru & 0,98 & 1,00 & $-0,02$ \\
\hline 6. & Guru minta maaf kepada murid apabila melakukan kesalahan & 0,82 & 0,88 & $-0,06$ \\
\hline 7. & Saya merasa kehilangan apabila guru berhalangan mengajar & 0,87 & 0,90 & $-0,03$ \\
\hline 8. & Guru tidak berlaku kasar pada murid & 0,87 & 0,84 & 0,04 \\
\hline
\end{tabular}


swasta yang sudah dan belum disertifikasi. Dari 8 butir pertanyaan, sebanyak 7 pertanyaan $(88 \%)$ yang perbedaan proporsi jawabannya kurang dari atau sama dengan $5 \%$. Hasil ini dapat memberikan gambaran bahwa tidak terdapat perbedaan kompetensi sosial/kepribadian yang berarti antara guru SMP negeri yang sudah dan belum disertifikasi.

Untuk melihat apakah terdapat perbedaan kompetensi secara umum antara guru SMP swasta yang sudah dan belum disertifikasi, dikalkulasi selisih proporsi siswa yang menjawab 'Ya' atas pertanyaan yang diajukan. Dalam Tabel 12 a dan 12 b terlihat bahwa dari 23 butir pertanyaan ada 16 butir pertanyaan (70\%) yang perbedaan proporsi jawabannya negatif. Perbedaan proporsi negatif menunjukkan bahwa kompetensi guru SMP swasta yang belum disertifikasi lebih baik daripada yang sudah disertifikasi. Sebaliknya terdapat sembilan butir pertanyaan $(30 \%)$ yang perbedaan proporsi jawabannya positif. Perbedaan proporsi positif ini menunjukkan bahwa kompetensi guru SMP swasta yang sudah disertifikasi menurut persepsi siswa lebih baik daripada guru yang belum disertifikasi. Menyimak bahwa persentase butir pertanyaan yang perbedaan proporsi jawabannya negatif lebih besar daripada yang perbedaan proporsi jawabannya positif yaitu $70 \%$ berbanding 30\%, maka dapat dikatakan bahwa kompetensi guru SMP swasta yang belum disertifikasi lebih baik daripada yang sudah disertifikasi.

Pada bagian pendahuluan telah disajikan hasil UKG 2015 dan tiga hasil kajian terdahulu tentang kompetensi guru antara yang sudah dan belum disertifikasi terfokus pada membandingkan kompetensi pedagogik dan kompetensi profesional. Kedua kompetensi ini memang yang paling mudah diukur dibandingkan dengan dua kompetensi lainnya yaitu sosial dan kepribadian. Hasil ketiga kajian menunjukkan bahwa tidak terdapat perbedaan kompetensi profesional yang berarti antara guru yang sudah dan belum disertifikasi. Namun, untuk kompetensi pedagogik hasil ketiga kajian ini tidak sama. Kajian oleh Brotosedjati (2012) dan oleh Nasir, dkk. (2013) hasilnya menunjukkan bahwa kompetensi pedagogik guru yang sudah disertifikasi lebih baik daripada yang belum disertifikasi; sedangkan hasil kajian Suarman dan Syahza (2014) menunjukkan bahwa tidak terdapat perbedaan kompetensi pedagogik antara guru yang sudah dan belum disertifikasi. Kajian Brotosedjati (2012) dan Nasir dkk. (2013) berbeda dengan hasil kajian Suarman dan Syahza (2014) ini bisa saja terjadi karena guru yang sudah disertifikasi sudah mengikuti pelatihan dimana dalam pelatihan tersebut guru mendapat metode pembelajaran baru yang kemudian diterapkannya sehingga membuat kompetensi pedagogiknya lebih baik daripada rekannya yang belum disertifikasi. Selanjutnya jika dibandingkan dengan hasil UKG 2015 yang lingkupnya nasional, yang hasilnya menunjukkan bahwa rerata nilai UKG antara guru SD yang sudah dan belum disertifikasi kurang lebih sama dan masih lebih rendah dari standar kelulusan/ capaian minimal (SKM) UKG yang ditetapkan yaitu 55,0; kemudian rerata nilai UKG guru SMP yang reratanya memang sudah di atas SKM, namun reratanya kurang lebih sama antara guru yang sudah dan belum disertifikasi. Berdasarkan perbandingan tersebut dapat disimpulkan bahwa tidak terdapat perbedaan kompetensi pedagogik dan profesional yang berarti antara guru yang sudah dan belum disertifikasi, karena kompetensi yang dites dalam UKG adalah kompetensi pedagogik dan profesional.

Jika dibandingkan antara kajian terdahulu, capaian UKG 2015 dengan hasil kajian ini, diketahui bahwa tidak terdapat perbedaan kompetensi pedagogik dan profesional yang berarti antara guru yang sudah dan belum disertifikasi. Khusus untuk kajian ini, ditunjukkan pula bahwa tidak terdapat perbedaan kompetensi kepribadian dan sosial yang berarti antara guru yang sudah dan belum disertifikasi. 


\section{SIMPULAN DAN SARAN}

\section{Simpulan}

Simpulan umum yang dapat ditarik dari temuan pengkajian ini adalah bahwa menurut persepsi siswa tidak terdapat perbedaan kompetensi yang berarti antara guru yang sudah dan belum disertifikasi. Simpulan ini sejalan dengan hasil UKG 2015 dan juga hasil studi terdahulu yaitu tidak terdapat perbedaan kompetensi yang berarti antara guru yang sudah dan belum disertifikasi. Simpulan ini tidak sesuai dengan hipotesis awal kajian ini bahwa kompetensi guru yang sudah disertifikasi harus lebih baik daripada yang belum disertifikasi. Bahwa tidak terdapat perbedaan kompetensi yang berarti antara guru yang sudah dan belum disertifikasi, ini didasarkan pada kenyataan bahwa proporsi siswa yang menilai kompetensi gurunya yang sudah disertifikasi tidak banyak berbeda dengan proporsi siswa yang menilai kompetensi gurunya yang belum disertifikasi. Perbedaan proporsinya umumnya sangat kecil yaitu kurang dari lima persen untuk hampir semua item pertanyaan untuk mengukur kompetensi guru.

Simpulan tentang perbedaan kompetensi antara guru yang sudah dan belum disertifikasi menurut satuan dan status pendidikan (SD/SMP) adalah sebagai berikut: 1) di SD negeri, siswa berpendapat bahwa kompetensi guru yang sudah disertifikasi lebih baik daripada guru yang belum disertifikasi. Simpulan ini sesuai dengan hipotesis awal. Simpulan ini diambil karena dari 23 pertanyaan terkait indikator empat kompetensi yang harus dikuasai seorang guru profesional, sebanyak 15 butir pertanyaan $(65 \%>50 \%)$ perbedaan proporsinya positif; 2$)$ di SD swasta, siswa juga ber-pendapat bahwa kompetensi guru yang sudah disertifikasi lebih baik daripada guru yang belum disertifikasi. Simpulan ini sesuai dengan hipotesis awal. Simpulan ini diambil karena dari 23 pertanyaan terkait indikator empat kompetensi yang harus dikuasai seorang guru profesional, sebanyak 13 item pertanyaan $(57 \%>50 \%)$ perbedaan proporsinya positif; 3) di SMP negeri, siswa berpendapat bahwa kompetensi guru yang belum disertifikasi lebih baik daripada yang sudah disertifikasi. Simpulan ini tidak sesuai dengan hipotesis awal. Simpulan ini diambil karena dari 23 pertanyaan terkait indikator empat kompetensi yang harus dikuasai seorang guru profesional, hanya 10 item pertanyaan $(43 \%<50 \%)$ perbedaan proporsinya positif; 4$)$ di SMP swasta, siswa juga berpendapat bahwa kompetensi guru yang belum disertifikasi lebih baik daripada guru yang sudah disertifikasi. Simpulan ini tidak sesuai dengan hipotesis awal. Simpulan ini diambil karena dari 23 pertanyaan terkait indikator empat kompetensi yang harus dikuasai seorang guru profesional hanya tujuh item pertanyaan $(30 \%<50 \%)$ perbedaan proporsinya positif.

\section{Saran}

Saran untuk guru sebagai objek kajian, untuk guru SD baik di sekolah negeri maupun swasta, yang dinilai siswa bahwa kompetensi guru yang sudah disertifikasi lebih baik daripada yang belum disertifikasi. Guru yang sudah disertifikasi diharapkan terus meningkatkan kompetensinya, antara lain dengan memanfaatkan sebagian dari TPG-nya untuk mengembangkan diri, misalnya membeli buku pegangan guru, pengadaan laptop dan berlangganan internet agar tidak ketinggalan teknologi pembelajaran. Untuk Guru SMP baik negeri maupun swasta, yang dinilai siswa bahwa kompetensi guru yang belum disertifikasi justru lebih baik daripada yang sudah disertifikasi. Hal ini harus menjadi tantangan tersendiri bagi guru yang sudah disertifikasi. Guru-guru tersebut seharusnya terus berupaya meningkatkan kompetensinya dengan berusaha mengembangkan dirinya sebagai seorang guru profesional, terlebih bagi yang telah mendapat TPG dari pemerintah. Cara yang dapat ditempuh sama dengan yang disebutkan pada saran untuk guru SD. Selain itu guru SMP disarankan agar lebih mengaktifkan diri untuk mengikuti kegiatan belajar dari teman sejawat melalui Musyawarah Guru Mata Pelajaran (MGMP) baik internal maupun eksternal sekolah. Saran untuk Ditjen GTK perlu dilakukan evaluasi terhadap 
pelaksanaan sertifikasi guru karena sertifikasi guru yang dilakukan selama ini kurang dapat meningkatkan kompetensi guru, terbukti dari tidak terdapat perbedaan kompetensi yang berarti antara guru yang sudah dan belum disertifikasi. Temuan studi ini bahkan menunjukkan bahwa untuk kasus di SMP justru kompetensi guru yang belum disertifikasi lebih baik daripada yang sudah disertifikasi.

\section{PUSTAKA ACUAN}

Alim, M.N. 2013. Kinerja Pegawai Kantor Dinas Sosial, Tenaga Kerja \& Transmigrasi Kabupaten Polewali Mandar (Studi Kasus Pada Bidang Tenaga Kerja). Skripsi. Makassar: Jurusan Ilmu Administrasi Program Studi Administrasi Negara Fakultas Ilmu Sosial Dan Ilmu Politik Universitas Hasanuddin.

Apriliani, S.F. 2015. Peran Guru Dalam Meningkatkan Minat Berwirausaha Siswa SMK 17 Magelang. Skripsi. Yogyakarta: Fakultas Ekonomi Universitas Negeri Yogyakarta.

Azizi, A.L. 2010. Analisis Kesesuaian Guru Mata Pelajaran Dengan Latar Belakang Akademik Di MTs Sudirman Tempuran Kabupaten Magelang (Tinjauan Standar Nasional Pendidikan). Skripsi. Yogyakarta: Fakultas Tarbiyah Universitas Islam Negeri Sunan Kalijaga Yogyakarta.

Baeti, N. 2015. Pengaruh Sertifikasi Terhadap Kinerja Guru SMA Negeri di Kabupaten Sleman. Skripsi. Yogyakarta: Fakultas Ekonomi Universitas Negeri Yogyakarta.

Brotosedjati, S. 2012. Kinerja Guru Yang Telah Lulus Sertifikasi Guru Dalam Jabatan. Jurnal Manajemen Pendidikan Universitas Veteran Bangun Nusantara Sukoharjo, 1(2), 189-199.

Fajarini, C.D., Parwanto, Marpaung, L., \& Sabon, S.S. 2010. Studi Tentang Perbandingan Kinerja Guru Yang Sudah Bersertifikat Pendidik Dan Yang Belum Bersertifikat Pendidik. Laporan Penelitian. Pusat Penelitian Kebijakan Badan Penelitian dan Pengembangan (Puslitjak Balitbang) Kemendikbud.

Hasbullah, 2010. Sertifikasi Bagi Profesionalisme Guru Dan Upaya Peningkatan Mutu Pembelajaran (Studi kasus pada Guru Madrasah Aliyah Negeri Salatiga Tahun 2010). Skripsi. Salatiga: Jurusan Tarbiyah Program Studi Pendidikan Agama Islam Sekolah Tinggi Agama Islam Negeri (STAIN) Salatiga.

Jailani, M.S. 2014. Guru Profesional dan Tantangan Dunia Pendidikan. Jurnal Al-Ta'lim, 21(1), 19.

Lestari, S. 2010. Pengaruh Sertifikasi Guru Terhadap Kinerja Guru MTs N Mlinjon Filial Trucuk Klaten. Skripsi. Yogyakarta: Fakultas Tarbiyah Universitas Islam Negeri Sunan Kalijaga Yogyakarta.

Medistiara, Y. 2016. Nilai Rata-rata UN SMP Tahun 2016 Turun 3 Poin dari Tahun Lalu, http:// news, detik,com/berita/3230382/nilai-rata-rata-un-smp-tahun-2016-turun-3-poin-daritahun-lalu, diakses tanggal 3 Oktober 2016.

Mustofa. 2007. Upaya Pengembangan Profesionalisme Guru Di Indonesia. Jurnal Ekonomi \& Pendidikan, 4(1), 76-88.

Nasir, M., Samingan \& Abdullah. 2013. Komparatif Kinerja Guru Biologi Yang Belum Sertifikasi Dengan Guru Biologi Yang Sudah Sertifikasi Pada SMA Negeri Rayon 01 Kabupaten Pidie. Jurnal Biologi Edukasi Universitas Syiah Kuala Banda Aceh, 5(2), 60 - 65. 
Natsir, N.F. 2007. Peningkatan Kualitas Guru dalam Perspektif Pendidikan Islam. Jurnal Educationist, I(1), 20-27.

Novauli, F.M. 2015. Kompetensi Guru Dalam Peningkatan Prestasi Belajar Pada SMP Negeri Dalam Kota Banda Aceh. Jurnal Administrasi Pendidikan Pascasarjana Universitas Syiah Kuala, 3(1), $45-67$.

Kementerian Pendidikan dan Kebudayaan. 2012. Data Studi Sertifikasi Guru (Studi Longitudinal 2009-2012) dalam Proyek Better Education through Reformed Management and Universal Teacher Upgrading (BERMUTU). Jakarta: Badan Penelitian dan Pengembangan, Kementerian Pendidikan dan Kebudayaan.

Kementerian Pendidikan dan Kebudayaan. 2015a. Data Uji Kompetensi Guru 2012-2015. Jakarta: Direktorat Jenderal Guru dan Tenaga Kependidikan Kementerian Pendidikan dan Kebudayaan.

Kementerian Pendidikan dan Kebudayaan. 2015b. Statistik Persekolahan 2015. Pusat Data dan Statistik Pendidikan Sekretariat Jenderal Kementerian Pendidikan dan Kebudayaan (PDSP Setjen Kemendikbud).

Mudri, M.W. 2010. Kompetensi Dan Peranan Guru Dalam Pembelajaran. Jurnal Falasifa, 1(1), 111-124.

Qurrotu, A. 2011. Penilaian Kinerja (Performance Appraisal) pada Karyawan di Perusahaan. Majalah I/miah Informatika, 2(3), 74-88.

Republik Indonesia. 2005. Undang-Undang Nomor 14 Tahun 2005 tentang Guru dan Dosen. Rohman, M.K.A. 2007. Faktor-Faktor Yang Mempengaruhi Kinerja Guru Dalam Melaksanakan Pembelajaran Studi Kasus pada SMK Berdikari Jember. Skripsi. Malang: Program Studi Pendidikan Teknik Bangunan Universitas Negeri Malang.

Sari, B.R.F. 2014. Pengaruh Persepsi Guru Mengenai Sertifikasi Guru Dan Akreditasi Sekolah Terhadap Motivasi Kerja Guru SMA Negeri Di Kabupaten Temanggung. Skripsi. Yogyakarta: Fakultas Ekonomi Universitas Negeri Yogyakarta.

Setyaningsih, N. 2015. Evaluasi Kompetensi Guru Dalam Mengimplementasikan Kurikulum 2013 Di SD Negeri Kejambon 2 Kota Tegal. Skripsi. Semarang: Fakultas Ilmu Pendidikan Universitas Negeri Semarang.

Setiyawan, D. 2013. Peran Guru Dalam Meningkatkan Minat Belajar PKn Pada Siswa Kelas III Di MIN Tempel Ngaglik Sleman Yogyakarta. Skripsi. Yogyakarta: Fakultas IImu Tarbiyah dan Keguruan Universitas Islam Negeri Sunan Kalijaga Yogyakarta.

Siswanto. 2008. Program Sertifikasi Guru (Antara Tuntutan Kesejahteraan dan Kualitas). Jurnal Pendidikan Islam Tadris, 3(2), 211-221.

Siswanto. 2010. Tingkat peguasaan Keterampilan Dasar Mengajar Mahasiswa Prodi: Pendidikan Akuntansi Fakultas IImu Sosial dan Ekonomi Universitas Negeri Yogyakarta. Jurnal Pendidikan Akuntansi Indonesia, VIII(2), 41-51.

Suarman \& Syahza, A. 2014. Dampak Kebijakan Sertifikasi Terhadap Kinerja Guru di Daerah Riau. Jurnal Pendidikan Lembaga Penelitian Universitas Riau Pekanbaru, 4(2), 72-83.

Suharso, Y. 2013. Peran dan Tanggungjawab Guru Sebagai Tenaga Profesional. Majalah Ilmiah Pawiyatan, XX(4), 112-123. 
Sunhaji. 2014. Kualitas Sumber Daya Manusia (Kualifikasi, Kompetensi dan Sertifikasi Guru). Jurnal Kependidikan, II(1), 142-160.

Undang-Undang Nomor 14 Tahun 2005 Tentang Guru dan Dosen.

Wuryanti, Idris, A. \& Djaja, S. 2014. Dampak Tunjangan Profesi (Sertifikasi Guru) Dalam Optimalisasi Kinerja Kepala Sekolah Dasar Kecamatan Samarinda Ulu. Journal Administrative Reform, 2(1), 1123-1134. 